


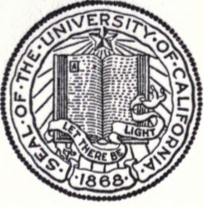

THE LIBRARY

OF

THE UNIVERSITY

OF CALIFORNIA

LOS ANGELES 
Eb. 1950 


\section{Studies in Nature}

\section{- - and Country Life}





\section{STUDIES IN NATURE}

\& COUNTRY LIFE $\varnothing$

By CATHERINE D. WHETHAM and W. C. D. WHETHAM, M.A., F.R.S., Fellow of Trinity College, Cambridge

CAMBRIDGE MACMILLAN \& BOWES MIMIII 
CAMBRIDGE

PRINTED BY JONATHAN PALMER

ALEXANDRA STREET 


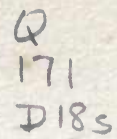

We wrote this book to help our children in days to come to look on the world around them with observing eyes and understanding minds. We publish it in the hope that it may help other people's children, and bring profit to our own.

October 1903. 


\section{CONTENTS}

\section{PART I}

CHAPTER

PAGE

I. NATURE AND OBSERVATION . . . . . I

II. EARTH . . . . . . . . 8

III. AIR . . . . . . . . . . 16

IV. WATER . . . . . . . . . 23

V. HEAT . . . . . . . . . $3 \mathrm{I}$

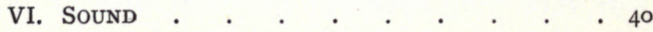

VII. LIGHT AND COLOUR . . . . . . $5 \mathrm{I}$

VIII. ThE Weather . . . . . . . 6I

\section{PART II}

IX. The Country and its Names . . . 75

X. ROADS . . . . . . . . . . 82

XI. SPRINGS AND StrkamS . $\quad . \quad . \quad . \quad . \quad . \quad 87$

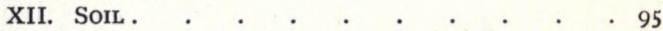

XIII. FIELdS AND Hedgerows . . . . . . 103

XIV. TREES AND WOODS . . . . . . I IO

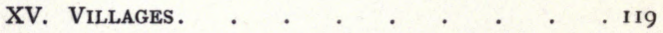


PART I 



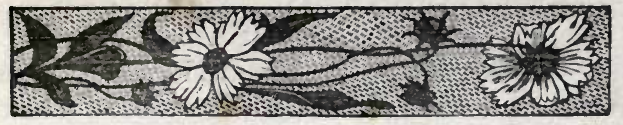

\section{CHAPTER I}

\section{NATURE AND OBSERVATION}

THE study of Nature is a delightful occupation. There is no time of day when it cannot be taken up; there is no period of life when it cannot be pursued in some way or another; there is no part of the earth where rich material is not lying ready to hand. It is an occupation in which there is endless variety, endless opportunity and endless profit. There is an unfailing source of pleasure and interest open to us all, provided only that we possess two things. The first is a desire to observe and understand what we see around us, and the second is the power to do so intelligently.

It may be said that those who are compelled to spend their lives in cities are perforce cut off from much intercourse with Nature, except human Nature, and that certain kinds of occupation, coal-mining or engine-driving for instance, must make any study of the world around us a very difficult matter. It is certainly true that opportunities will be less frequent, and the outlook will not be so wide. Still, nothing that the builders of big cities can 


\section{STUDIES IN NATURE}

do will take away from the dwellers therein the whole of the sky; the greater part will always be left where they can watch the movements of the clouds, gathering up knowledge of wind and weather, and noting the changes of the moon and the nightly journeyings of the stars. Great artists have found many of their most beautiful effects of colour in crowded streets, and have delighted to paint the sunset colours, seen through a veil of smoke. Moreover, in towns we find parks and open spaces in wisely increasing numbers; there are trees and plants, sparrows and starlings, perhaps even rooks and wild pigeons. There are seagulls that come inland on stormy days, and other strange birds that fly overhead in their yearly change of home. All these have different habits of life, well worth careful study, for each represents some part of the scheme of Nature. Even if, as an extreme case, we are forced to spend much of our time in mines under the surface of the earth, we need not despair. The rocks around us are part of Nature, differing among each other. Some will be soft, others hard; some will be useful, others must be left aside. Some will tell the intelligent workman that danger is at hand; by noticing others he will know that he can safely continue his labours. As long as we live on this earth we may be very sure that we cannot get away from Nature. 


\section{NATURE \& OBSERVATION}

Most of us, I believe, have far more chances of living with Nature and of trying to understand the meaning and beauty of the world around us than we are at all able to profit by. We have eyes but we do not see, we have ears but we do not hear, and so we go through life, missing half the pleasures that have been prepared for us, and understanding but a small part of what we do not miss. Let us therefore try to learn, while we may, how to make good use of our time.

The best way to begin is to go out into the country for a little while and look about us, and then, when we have remembered and thought over what we have seen, go again to find out if the things we notice are still there and look the same as they did before. Some of the ones we saw at first will have altered and new ones will have appeared. By going out at different times of the day and different seasons of the year we shall soon know what there is to be seen. This is the way in which artists and poets study the world, and find out a great deal more about it than most of us will ever do. They will not perhaps spend much time in the fields, but they will see a great deal, and remember some special part of what they have seen. They have this wonderful gift of observation. Moreover, they can afterwards tell us what they have seen, and can put down the meaning of it to them in colours or in words for us to study. 


\section{STUDIES IN NATURE}

Another way of beginning is to read what these lovers of Nature have written, and then go out and see if we can find the things they describe. The world will never look quite the same to any two people, since we ourselves, the observers, are all of us a little different from each other, and see it at different times and seasons. It will help us in our study, therefore, if we try at once to notice differences, and think what has brought them about. Because we see things differently, it does not always follow that other people are wrong, or that our eyes have led us astray. There are really as many different ways of looking at the world as there are people to look at it. Each new way is of use, and teaches us to understand more of what is happening around us. This book is written to help those who wish to help themselves, and it should be put aside as soon as the reader can see all or more than it tells about.

When we set out to explore the world around us, we must be careful, as the result of our inquiries, not to burden our minds with too many useless facts. We don't try to know the exact height and weight of our friends; we don't always remember the colour of their eyes and hair, their age does not matter to our friendship. We understand them, we are fond of them, and we know them again whenever we meet. In the same way we must not burden our minds and memories too much when we go 


\section{NATURE \& OBSERVATION}

out to study Nature and make friends with her; we must not trouble ourselves with unimportant details. It does not in the least matter how many trees there are in a group, unless we intend either to sell or buy them, nor how high a hill is, nor how fast the wind travels, nor how many sheep there are in a flock, nor how many cows in a meadow. We are neither timbermerchants, engineers, wind-mills, shepherds, nor farmers. We shall do wisely at first if we think only of such things as we believe to be beautiful, or hope will help us to understand the world we live in.

It will be useful, in the first place, if we try to find out what powers of observation we have; whether we do usually notice the objects around us, whether we remember correctly what we have seen, or whether we are in the habit of walking about with our eyes open and our minds shut. Can we, for instance, draw a plan of the house we live in, putting the doors and windows on the right walls? Do we know how the roads and paths go in the gardens and parks with which we are familiar? There are some pieces of ground we walk over almost every time we go out. Are they paved with flag-stones or cement? Are they covered with gravel or asphalte? Are they just the hard earth trodden down, which is good to walk on in fine and dry weather, but becomes a mass of mud after a 


\section{STUDIES IN NATURE}

long spell of wet weather? And again, we may ask ourselves whether the gravel is red or yellow or gray, and what sort of earth we are treading under foot. If we can answer all these questions fairly correctly, and can draw a tolerable map of our house and the roads about us, and know which window the sun shines in at in the morning, and where we can best see the sunsets at different times of the year, we may feel pretty sure there is nothing much wrong with our powers of observation, and that we have only to go on looking about us to get a great deal of pleasure and information.

This question of where the sun is to be found is very important, much more so than people, who have not considered the matter, are apt to think. The whole of life on this globe really depends on the sun; the plants grow because of the warmth and light they get from it, they store up the radiation in a different form of energy, and we get some of it back from them again when we use them as firewood, or when we dig out the remains of trees that grew many thousand years ago and burn them as coal. It makes a real difference whether a house or a piece of ground gets a little more or less sunshine, especially in the British Isles, where we have a great deal of cloudy weather. Let us look in the shady parts of a garden, or behind a wall, where the sun's rays never reach 


\section{NATURE \& OBSERVATION}

the ground, and we find poor shabby plants that seem to have a hard struggle for existence, or else such things as ivy and a few other forms of vegetable life that have learnt how to live without much sunshine. All the plants that men or animals use for food require light and warmth, and we ourselves also become stronger and healthier in sunlit rooms. Grass grows in the open fields and in the shaded woods; let us look carefully and see if it seems to be the same in both places; and notice which sort the cattle and sheep prefer, if they have the choice. There is all the difference in the world between the north side of a wall and the south side, as any gardener will tell us; and a great deal of difference between the north slope of a hill and the south slope, although the sun may shine even on the north side for many hours of the day. We already know a good deal about any piece of ground if we know whether it faces east or west, north or south. 


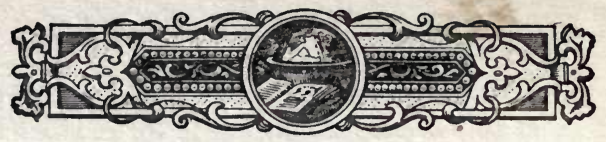

\section{CHAPTER II}

EARTH

Probably we have been told several facts about this earth we live on which seem rather surprising to us, and I suppose we most of us remember some of them. We have been told that the earth is more or less round, that it travels perpetually through space, that there is a strange force called 'gravity' binding it in some mysterious way to the sun, and drawing all things on the earth to the earth. We probably could not have found out these facts ourselves, and, though we believe them to be true, they hardly enter into our every-day life. We still speak of the sun rising and setting, not of the earth turning towards, or away from, the sun; nor do we usually recollect that the ground we walk on is moving through space at the rate of something like nineteen miles a second, carrying us and everything else, even the very air we breathe, along with it. As we see it, and as we think of it, the earth appears a solid immoveable surface, with ups and downs all over it, which, if they are big, we call mountains and valleys. There is the sky above it; there is the 


\section{E A R T H}

sun in the day-time, unless it is hidden behind clouds; there is sometimes the moon, which, if we look carefully, we shall find never seems the same shape two days running; there are the stars at night, and there are clouds of all sizes, shapes and colours. There is generally water to be seen somewhere in our landscape; it may be that on one side our outlook is bounded by the sea; there may be a river running down the bottom of our valley, or a small lake lying at the foot of the hills, or perhaps only a pond in a field for cattle to drink at. These three then, earth, sky and water, seem to make up the world we know.

In this chapter we will try to learn a little more about the earth, its hills and valleys, its plains and watersheds. If the hills around us are at all steep, we shall find pieces of rock, stone, chalk, or some such hard substance, standing out up the sides or on the top, while the low-lying parts beneath them are almost entirely covered with soil. Now the rocks are so hard and firm that it seems difficult to believe that the soil below is chiefly made up of little grains of stone that have been broken or worn off the mountains and carried down by the streams. Yet, if we look more closely at the rocks, we shall notice little grooves, or markings, perhaps even find tiny bits that are almost ready to break away and leave a fresh piece exposed to the influence of the sun and 


\section{STUDIES IN NATURE}

rain. Water, especially when it is in the form of rain, has the power of dissolving certain substances in the rocks and soil, and carries them away invisibly with it down the streams. In the same way we lose sight of a piece of sugar if we leave it to melt in a cup of tea, yet know it is there from the taste. Indeed, we could find it again if we were to boil away all the water, although it would be mixed with other substances out of the tea and milk. By thus dissolving some parts of the rock, the water will break them up, or, at all events, will cut little channels in them. In these channels, or in other cracks, the water lodges; in winter this water freezes and, as we shall see later on, expands, splitting open the cracks still further with very great force. Thus the rocks crumble away, and their particles are carried off, visibly or invisibly, by rain-storms and floods.

Let us look carefully at any stream or moving water that we can find. In many places there are little pebbles and other pieces of rock rubbing themselves down against each other; here and there are banks of fine sand and mud which are hardly to be distinguished from the soil of the fields. A short walk by the river-side will soon teach us that the hills and slopes whence the water comes, whether they are near at hand where we can see and climb up them, or so far off that they only appear as a blue line on the horizon on clear 


\section{E A R T H}

days, are slowly and surely being worn away and made low, while the valleys will gradually be filled up with the tiny grains that were once on the hill-side.

How the land and sea and mountain-ranges were first made is a very difficult question, and one that I do not think we could answer from our own observation. To understand even a little about it we should have to talk with the men who have studied such questions, the geologists, as they are called, and read the books they have written on the subject. They would tell us that banks of sand and soil brought down by the rivers, many thousand years ago, have been left at the bottom of valleys and lakes, and pressed closely together, layer upon layer, until once more they hardened into rock. In the same way, as the little particles of sand or the tiny remains of sea-animals and plants fall slowly down through the waters of the ocean, a fine covering of mud and ooze is formed at the bottom of the sea. Then the surface of the earth has gradually moved up and down, until in places the bottoms of sea and lake have risen up to become dry land, and the land itself, in its turn, sunk under the water. Sometimes too, in far off ages, the face of the earth seems to have crumpled up, much as we might crumple up a copy-book or door-mat if we were to push the two ends towards each other, and these movements have made the great mountain- 


\section{STUDIES IN NATURE}

ranges, which in their turn are now being destroyed by the constant wearing away of rain and ice. Such movements are still taking place, although we can hardly hope to notice them; except perhaps at the sea-side, where it is easier to find out year by year how far the sea comes up the face of the cliffs or goes out over the sand.

Great sudden changes must also have occurred in the dim past, but such movements of the earth as these, have now, happily for us, for the most part ceased; although something of the same kind still occurs when there are earthquakes and volcanic eruptions.

Sometimes we come across large tracts of country which seem almost flat; there are neither hills nor valleys to be seen, and the rivers, if there are any, crawl through them as though they hardly knew which way to flow to reach the sea. These tracts of country are called plains, and at first sight are apt to appear uninteresting. If they are on high ground we shall probably find them dry and waterless, for the rain will sink into the ground, since there are no little hollows and slopes for it to gather in and run down; unless indeed the rock will not let the water through, when it will collect in dull flat-edged lakes and swamps on the top. If the plain is low, the ground will be wet and marshy; there is a great deal of water, but it seems to get entangled in 


\section{E A R T H}

the soil and caught up by the roots of the plants, until perhaps men have actually to come and dig a way out for it, or put up banks and dykes, as they do in Holland, to keep the sea from finding a way in. Such flat low-lying districts are called in England 'fens,' and are to be found on both sides of the country; in Lincolnshire and in Cambridgeshire, and also in Somerset. To those who live near them and study them, these fenlands are very beautiful. The unbounded expanse of sky and country gives a wonderful sense of space and freedom; the moisture of the air above the damp earth seems to glorify the light, and the shadows of the clouds, if we can find a piece of raised ground to watch from, will be often seen chasing each other across the plain.

The mountains, the hills, and the high-lands divide the country up into groups of connecting river-valleys or watersheds, and in each of these watersheds the rain that falls will gradually find its way-first into the little streams, then into the larger ones, and at last into the big river at the bottom of the valley, which will carry it into the sea. It is not always easy near the top of a hill to know which way a stream will flow in the end, which river it will fall into, and whether that river will carry the water out into the North Sea, the English Channel or the Atlantic Ocean. Sometimes close at hand on high boggy ground we may find one stream- 


\section{STUDIES IN NATURE}

let out of a pool flowing down to the right, and another streamlet out of the same pool falling away to the left. They will run down different sides of the hill, each into a different valley, and we cannot always tell whether these valleys join together or belong to different watersheds.

We can see something of the same sort on any road during a rain-storm, for the ups and downs of the surface will send the water sometimes to one side and sometimes to the other, just as, on a much larger scale the hills divide the watersheds. Indeed, we need not wait for a shower, but can go out with a can of water and study the watersheds of the paths around us for ourselves. The only way to be certain, without asking, or looking at a map, which way a stream will flow in the end, would be to walk down the stream to the river, and down the river to the sea. If we live far from the sea we should most of us have neither time nor strength for such a walk; but as it is interesting to know whither the water near us is bound we may fairly look at our maps, which have been drawn by people who have taken this walk, or parts of it, and see what they have to tell us about the matter.

In the same way, if we live by the sea and look about us, we shall want to know where the river we see running out into the ocean comes from; what valleys and hill-sides it drains; what other towns and villages it passes through. 


\section{E A R T H}

These, as I said before, are things any of us could discover for ourselves if we went to look. We should certainly find out a great deal in a day's walk, and when we have done all we can by ourselves, we may take advantage of what other people are willing to tell us. 


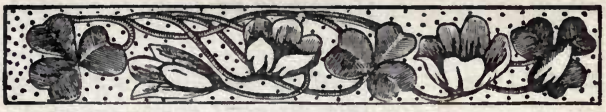

CHAPTER III

AIR

THE air differs from many of the other things we shall have to consider, in one striking way. We cannot see it; it is invisible. We can see the effects of its movements when the branches of the trees are swayed to and fro, or when the draught in a house makes a door slam or a chimney smoke. Now we are so much accustomed to getting our information through our eyes, that we are apt to forget that other senses will sometimes serve us quite as well.

On a still day out of doors, or in a quiet room, it is perhaps difficult to believe that we are surrounded with air; there does not appear to be anything. There is, as we said before, nothing to see. Yet we are just as much covered up by the air as a fish is by the water it swims in. The air is always there, on every side of us, whether in-doors or out-of-doors, both by night and by day. Yet, however still the air around us, there is one fact which ought to tell us it exists. We all breathe. We are all constantly taking something into our chests and sending it out again, only to take in 


\section{A I R}

a fresh supply. If we try to stop breathing we begin to choke, and after a very short while we are obliged to give in and draw a deep breath of this air. Animals breathe also; we can listen to any dog or cat that is lying asleep. They breathe as regularly as we do. We see their sides moving, just as we feel our own sides do. Trees and plants also breathe, although they do it in a different way, and it is more difficult to find out about them. What then is this air we are all breathing? Certainly it is a very important thing, worth taking a good deal of thought about, for we can none of us live without it.

Let us go up to a window on a cold day, or take up a piece of glass and breathe out upon it two or three good deep breaths. What do we find? Tiny drops of water have formed on the surface, and have evidently come out with our breath. If the glass had not been there to catch them they would have gone out into the space around us, as they usually do; so there must be water in some form in this air, and water also in our breath. Again, let us go into a room where the windows have not been opened for a long time, or a room in which there are a great many people. "What bad air!" we exclaim, and at once open the doors and windows to let in fresh air. Some people will faint if they have to stay long in a hot, close building, and only, recover themselves 


\section{STUDIES IN NATURE}

when they are carried out and laid down outof-doors.

All this shows us that, besides the water, there must be at least two other sorts of gases or vapours, by which name we call these substances we cannot see or handle, in the air around us. There is the good air which makes our rooms pleasant and healthy to live in, and there is the bad air that makes us feel faint and sickly. This good air or gas is called oxygen, while the bad air contains unpleasant vapours given off by our bodies, one of which is known as carbonic acid gas. We know now the names and some of the properties of this mixture of gases we call air; there is also a fourth substance, nitrogen, to be found in it, and it is present in much larger quantities than any of the other three. It does not take such an active part in our daily life, and seems merely to dilute or weaken the oxygen, as water may be used to dilute whisky or wine, which would be too strong for most of us alone.

When we open the windows we let into our rooms a fresh supply of air, and amongst the air comes in oxygen, without which we cannot live, while the used-up air goes out, taking the carbonic acid gas in it.

When we think this over we may well wonder how it is that there is any pure oxygen at all left in this world for us to breathe, seeing that the animals and plants also require it. Surely it 


\section{A I R}

should have been used up long ago! The carbonic acid gas is largely made up of oxygen, so is the water-vapour; every breath we take changes a little oxygen into carbonic acid gas and water ; in every fire that burns, coal, which contains a great deal of carbon, is taking oxygen out of the air, and burning it into carbonic acid gas, warming us as it does so. We can see this in a very simple way. If we light a candle, stand it up in a saucer of water, and then put over it a bottle or glass jar which touches the water on all sides, so that no more air can get in, the candle will go out after a short while because the flame has used up all the oxygen in the air inside, and cannot burn any longer without a fresh supply. Somewhere, clearly then, something must be dividing up the carbonic acid gas, and sending back the oxygen into the air to be used again. And we may also wonder what happens to this carbon, and what sort of stuff it is. Now carbon exists in many forms and shapes. There is a great deal of it in coal, as we shall see later on. Diamonds are almost pure carbon, and we sometimes hear people speak of coal as "black diamonds." The fat and flesh of animals and people is largely made up of carbon, and, most important of all for us, trees and plants and vegetables require great quantities of carbon.

We said above that the trees and other plants breathed somewhat like animals, at any 


\section{STUDIES IN NATURE}

rate that they took in oxygen and gave out carbonic acid gas. One of the reasons why many plants and trees will not grow in large towns is that their pores or breathing holes get filled up with soot and dirt, and the plant, being unable to breathe, is consequently choked. In the day-time, however, and most of all when the sun's rays fall directly on them, green plants also perform the reverse process of breathing to a much greater extent. They absorb carbonic acid from the air, and, using the energy of the sun's rays, divide it up, keeping the carbon to help make their leaves and stems, while the pure oxygen passes out again into the open air. Here, again, we see how the sun helps in all the important affairs of life, and we also learn how necessary it is to have plenty of trees and plants in the world. We now also understand how the carbon got into the coal, for coal, as we said before, is nothing but the remains of the forests and woods of bygone ages which have been slowly covered up, perhaps with the fine mud and sand that some great river brought down in the dim past.

We thus learn that air is principally a mixture of three gases, nitrogen, oxygen, and carbonic acid, and, in the open air, the amounts of these gases are always very nearly the same But the quantity of water-vapour, which we also know to be there, since it comes out with our breath like the carbonic acid gas, is always 


\section{A I R}

changing, and there is never the same amount of it present two days running. When water boils in a kettle, we know it comes out of the spout as steam or vapour, and is lost in the air ; if we leave a saucer full of water in the sun the water also gradually disappears, dries up or evaporates; and if we put the same saucer full of water out of doors on a hot day and again on a cold day, the water will disappear faster on the hot day than on the cold day, or faster in a hot room than in a cold room. Let us think for a few minutes if we have noticed anything which ought to have told us this.

The rooms of a house are in winter time warmer than the air outside, and if we wake up on a cold frosty morning and go to our windows, what shall we find on the window panes inside the room? Water, in drops on the glass, in little pools on the sills, or perhaps even in tiny crystals of ice all over the window. Where then did this water come from? Not surely through the glass or the window frames? Even when it rains outside we do not expect the water to come through, unless unfortunately there are actually holes somewhere that we know about and can see. The water has certainly come from somewhere inside the room. This is what has happened. The air was warm in the evening and held a certain quantity of water-vapour. During the night, the air near the glass got cold because the cold air outside chilled the window-panes 


\section{STUDIES IN NATURE}

and some of the warmth of the room escaped into space outside. The air near the window could not now hold as much water, and so some of it dropped out, or was deposited, on the cold glass, where we found it in the morning.

This is also the way in which dew forms on the ground on clear autumn evenings. The surface of the earth has been warmed by the sun's rays striking on it, by radiation, as we say, and has in turn warmed the air above it. At night, if there are no clouds to keep the earth warm, the surface radiates its heat back into space and gets cold. Then the air above it is chilled and deposits on the grass the water it can no longer hold. There is never much dew under trees because they act as a protection, just as the clouds do, radiating back to the earth some of the heat it is losing. In the same way, if we put a rug or mat over two chairs, and cover in a piece of ground, the surface will keep much drier than the open ground beside it.

Warm air, besides being able to hold more water-vapour than cold air, differs from it in another way that is of importance to us in our every-day life. It is lighter than cold air; that is to say, in a given volume or definite space, there is less air when it is warm than when it is cold. The warm air seems to spread itself out and require more room, and so there is less of it in a given volume. This makes it lighter, just 


\section{A I R}

as a box where we tumble the bricks in anyhow will hold fewer bricks and so be lighter than the same box if we pack the bricks in close and tightly. We can see this spreading out of warm air by making a very simple experiment. Let us get one of the toy india-rubber balloons that are sold in the street. If we put it too near the fire, it will burst, because the gas inside will expand more than the india-rubber skin is able to do. But if we keep it for a few days, until it gets limp and shabby, because the gas inside is gradually leaking out somewhere, and then warm it, it will fill out again and look quite good as long as it is warm. The cold air is heavier than the warm air, and if they are not mixed by moving objects the warmer air will quickly rise and the colder air will settle underneath it, on the floor in-doors or in hollows outside.

We all know that warm air goes up the chimney and carries the smoke along with it, while we have often felt cold air coming in through the doors and windows to take the place of the air that has gone up the chimney. If we do not leave sufficient room for fresh air to come in easily, it forces its way through cracks and crannies, and we then call these movements of the air draughts. Most people do not like draughts, and since we know now that this entrance of fresh air must take place somehow, we should try to arrange for a constant supply to come into our rooms in a way that will not be unpleasant. This is 


\section{STUDIES IN NATURE}

called ventilating a house, and is a matter that most people do not sufficiently attend to.

The great movements of the air in the world outside cause the breezes, winds, and gales, which have been familiar to us all from childhood. We shall learn more about these when we come to consider the subject of the weather. 


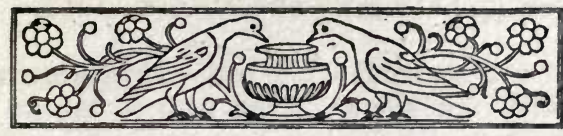

CHAPTER IV

WATER

In this chapter we are going to consider Water, and I hope we all of us know a great deal about it already. We certainly ought to, for we can see it, we can feel it, we drink it, we wash in it, we row our boats on it and sail our ships over it, we give it to our plants and animals to drink, we skate and slide on it when it is frozen, and it falls on us out of the clouds as rain and snow. It is to be found on all sides of us, and we cannot imagine what the world would be like without it.

What is the water made of? Is it just water, something that we cannot divide or put together again? I do not think this is very important for us to know about at present, for we are not at all likely to want to make or split it up. Still, we could do so, and if we did, we should get a certain quantity of the gas we have called oxygen and about twice as much by volume of another gas that is known as hydrogen. These two, then, are the constituent elements of water, that is, they compose, or make it up. Although it is not probable that we shall require to know much 


\section{STUDIES IN NATURE}

about the composition of water, it is clear that we shall not always meet with water in the same form. We said that it was always present as invisible vapour in the air, we know it best as 'water,' but we must not forget that the frost will turn it into solid ice, when it again has quite a fresh set of properties. Water, then, can exist in three states: as solid ice, as liquid water, as gaseous vapour. Let us now consider how it differs in these three states of its existence.

We said before that when it took the form of vapour in the air we could neither see nor consciously touch it. Our reason told us that, like the air, it must be on all sides of us. A slight chilling of the air will sometimes make our vapour come back to us as liquid water. We can now see it and touch it, but we can hardly be said to be able to handle it, for it has no shape of its own, and will take the shape of any vessel or glass it is placed in. A little more chilling, a little more heat taken away from it on a cold frosty night, and our water is changed into ice, which we can see, touch and handle. We break a piece off; it keeps its shape, unless we hold it too long in our warm hands or take it into a hot room, when it begins at once to absorb heat and transform itself back into water. The question whether we shall find our water in the solid, liquid, or gaseous state depends only on the amount of heat there is 


\section{W A T E R}

present in it, and this applies to all other substances.

I think we are most familiar with water in its liquid state; iron, silver, gold, copper, and other metals are best known to us as solids. There is one metal, however, which exists as a liquid at the temperature we live in, and that is mercury, or quicksilver; but it too can be made to freeze into a solid like iron or gold if we can arrange to take away a sufficient quantity of heat. Air, and the gases which compose it, are, as we can tell, generally about us as gases or vapours. Still, some of us may have heard of people who can make and have uses for liquid air and liquid oxygen.

When water evaporates, and is transformed into vapour, it seems to disappear into the air, and we do not think much about it again until it reappears near us as rain, fog, snow, or dew. As the air which contains the water-vapour moves about, it often ascends into the colder regions of the sky above. There it is chilled, and in consequence some of the water-vapour is deposited in minute drops, or tiny ice crystals, so small that they can only fall very slowly through the air, and thus float about and appear as clouds. These little drops have often some difficulty in forming, even when the air is sufficiently cold to allow them to do so ; they seem to want a start, and often begin collecting round a speck of dust; in hailstones, for instance, we 


\section{STUDIES IN NATURE}

can sometimes see the nucleus or centre round which they have formed.

It is very interesting to watch these banks or layers of water-vapour as they float about in the air, disappearing again when they come to a warmer current of air. There are, as we all know, many different sorts of clouds, some of which are connected in our mind with certain sorts of weather, and we can learn a great deal about the state of the air above us if we watch the movements of the clouds. When the drops of water have grown to a certain size they fall to the ground as rain, drawn down by that force called gravity, which holds together the sun and the earth, and holds us on to the surface of the earth. When they are small, they fall so slowly that they seem able to float without falling, as we notice in a fog, which is more often dispelled or destroyed by the sunshine turning the tiny drops into vapour than by the drops themselves reaching the ground. In towns, where the smoke and dust in the air provide plenty of nuclei, fogs are often very thick and persistent, and prevent the sun's rays coming through. It is probable that in the highest clouds the vapour has been changed into ice, and the effects we see are due to the minute crystals of ice, and not to tiny drops of water.

Ice is lighter than water, and floats on the top of it. Perhaps this will seem strange, since cold water is heavier than warm water, and 


\section{W A T E R}

sinks to the bottom. We can feel this for ourselves if we lie in a warm bath and do not stir up the water. A layer of cooler water will begin to form at the bottom, while the warm water rises to the top, and uses up some of its heat in doing the work necessary to separate some of its particles and send them away into the air as vapour. All the time it is cooling the water contracts, its particles become closer together, which, as in the case of the air, or the box of bricks, makes it heavier. Just before it reaches the freezing point the process alters, and it actually begins to expand and spread itself out, as though the particles were re-arranging themselves in some way, ready to form the crystalline solid we call ice, and required rather more room to settle into their new places. So the water, which is nearly frozen, begins to rise again, and its place at the bottom is taken by water which is almost but not quite as cold, and when the ice is actually formed, we find it floating on the top of the water.

This is certainly a most wonderful provision of Nature. Let us think what some of the results would be if the ice were to sink to the bottom. Layer upon layer of ice would form and sink down until the ponds and rivers became a solid mass of ice, through which no fish could move, in which all animal and vegetable life would be suspended or destroyed. Then, when the warm weather came, the surface of the water 


\section{STUDIES IN NATURE}

would thaw and melt, but the great mass of ice far down underneath could hardly be reached by the hottest sun, and might not disappear all through the summer.

This expansion of water when it freezes accounts for the state of the roads and paths after a frost; it also assists the breaking up of rocks and of the soil; for the frozen water pushes the particles apart and makes the crevices bigger, so that the air and rain can afterwards get farther in to carry on their work of destruction.

Ice and snow both play a most useful part in keeping the ground, or the water below them, from losing any more heat. This protects the animal and vegetable life from the extreme cold, and it is a good thing in many ways for the country when a heavy fall of snow comes before a severe frost sets in. 


\section{CHAPTER V}

\section{HEAT}

WHEN we go into a room where there is neither sunshine nor a fire, nor anything else to make any part of that room hotter than any other part, we are right in thinking that all the objects in the room must be equally warm. This is expressed by saying that they are all at the same temperature. But if we put a hand on a stone mantelpiece or metal fender it will feel cold to us, while the curtain or carpet will feel quite warm. Again, let us get three basins or jugs and put cold water in one, hot water in another, and warm water in the third. Now if we put one hand in the cold and the other in the hot, and after a while move them both into the warm water, the hand that was in the cold water will feel it warm, and the hand that was in the hot water will feel it cold, although they are now both in the same basin of warm water. We sometimes speak of certain days in the middle of winter as being very warm, whereas if they had come in the middle of summer we should feel them to be very cold. What does all this mean? Are our senses at fault, or is there any 


\section{STUDIES IN NATURE}

reason why we should think the same thing to be both hot and cold when it is really all at the same temperature?

Let us consider the three cases we have taken a little more fully, and see if we can find out some explanation. In the first place there is certainly a great difference between stone and metal on the one hand, and the material out of which we make curtains or carpets. A brass fender before a fire may soon become so hot that we cannot touch it; we put a blanket over the fender and can touch it easily even though it is almost beginning to scorch. All the various sorts of stone and metal, marble, concrete, iron, silver, brass, feel cold to touch if they are cold, and seem almost to burn us when they are hot, while wood, flannel, wool, cotton, and such things, may be almost on fire before they become too hot to handle. Now these two sets of things are very different in many ways, and have very different properties, as we all know, and it is because of their differences in one particular way that we have these different feelings about them.

In order to find out which particular property is connected with this difference in our sensations when we touch different bodies at the same temperature, we must examine the bodies, and try to discover some one property which is possessed by all those which affect our senses in the same way. It will then be likely that this 


\section{HEA T}

property is the one which always creates the effect we are at present considering. Now there certainly is one property which is found to exist in all the substances like iron which give us extreme feelings of heat or cold. If we put an iron poker in the fire, or still better a brass rod, we shall find that heat gradually creeps along the poker or rod, and parts of it which are not actually in the fire soon become hot. On the other hand we know that it is perfectly easy to hold even a short stick of wood while the end of it is blazing, and if we put several thicknesses of flannel over our hand we can take a very hot kettle off the fire without being burnt. Here, perhaps, we see what is the difference between the two kinds of bodies. Heat can readily pass from one part to another in the iron or brass, while through the wood or flannel it can only creep with great difficulty. This difference is sometimes described by saying that iron and brass are good conductors of heat, while wood and flannel are bad conductors.

We have now discovered that the substances which feel very hot or cold when touched are good conductors, while those which we can always comfortably hold are bad conductors. If there is really any connexion between these two properties, we may perhaps be able to explain one by help of the other. What will naturally make our finger feel hot? We shall probably say a rise in its temperature. This 


\section{STUDIES IN NATURE}

can only be caused by the entry of heat faster than it is carried away. We shall thus look for an explanation from the rate at which heat can enter the finger. If it touches a bad conductor like flannel, some of the heat in the parts of the flannel which were actually in contact with the finger, will enter it, and its temperature will begin to rise. But heat cannot travel about the flannel at all easily, so when the heat in the parts touched is used up, very little more from the other parts reaches the finger, and that little will arrive so slowly that it is easily carried away before it can do any harm. On the other hand, if we touch hot iron, heat, not only from the parts we touch, but also from neighbouring regions, rapidly enters our finger, and we receive a vivid, perhaps even a painful, sensation. When the iron is cold, exactly the opposite thing happens. The heat of our finger is quickly conducted away, and a feeling of cold is produced. It is now clear that our sensations of heat and cold are not safe guides in finding the temperature of external objects; they really tell us at what rate heat is entering or leaving the part of our body which touches the object.

We now understand why it is foolish to lie or sit long on stone; it takes so much heat out of us that we feel chilled. We can see why we use blankets and other stuffs made of wool to keep ourselves warm in winter; they do not easily let the heat of our bodies pass away into 
the cold air outside. For the same reason, houses built of wood and felt can be made very warm. We see, also, that our hands told us the truth about the basin of warm water. The hand, that had been in the basin of hot water, had taken in a certain amount of extra heat beyond that which it naturally had in common with the other hand and the rest of the body; it gave some of this out again when it got into the third basin, and, as it was then losing heat, it told us that it felt cold. In the same manner the cold hand was getting heat from the warm water and truthfully told us this. A cold day means to most of us a day that is colder than the ones we have been recently accustomed to, and a hot day, one that is unexpectedly warmer.

Our feelings about whether things are giving heat to us or taking it from us, whether this is happening quickly or slowly, are wonderfully accurate, and, if we understand what they are telling us, we may safely rely on them. Indeed, we do so in all the ordinary affairs of life. But there are times when it would be neither wise nor indeed possible to do so. It would be foolish and useless to put a hand into a saucepan of very hot water to see if it were nearly boiling, for all that our feelings would tell us would probably be that the water was a great deal too hot to be pleasant. Yet this is a thing that we may often want to know, and a little instrument called a thermometer has been made 


\section{STUDIES IN NATURE}

to tell us what is the actual degree of heat or the temperature of the objects around us. There is a thermometer somewhere in most houses, in schoolrooms, in chemist's shops; and if we have not seen one already, we ought not to have much difficulty in getting someone to show us one. There are many different sorts of thermometers, depending on the purposes for which they are required, but I will describe a very common kind which we are all sure to come across sooner or later. It has a fine glass tube, closed at the top end so that nothing can get in ; at the bottom there is a small glass bulb which is filled with the grey liquid metal called mercury, and this goes partly up the tube. The glass tube has sometimes little marks or scratches on it by which we can measure how far the mercury has risen in the tube. Sometimes the glass tube and bulb are fixed on to a frame of wood, and the measuring marks are put on to that instead. The liquid metal mercury, which we mentioned in our last chapter, like the other metals we have just been speaking about, takes in and gives out heat very readily, and quickly becomes of the same temperature as the things around it. It has another useful property. Like water and air and most other substances, it expands and takes up more room when it is hot than when it is cold. The mercury in the glass bulb cannot expand there, for it has no room, as a sort of glass is chosen to make the bulb and 


\section{HEA T}

tube which is very little altered by heat. So the mercury has to expand up the tube, and goes further and further as it gets hotter. This gives us a measure of the temperature, for if we put our thermometer into boiling water, and then notice and mark how far the mercury has risen in the tube, and afterwards put it into freezing water, or surround it with melting ice, again noticing how far back towards the bulb the mercury has gone, we shall always be able to tell how near the freezing point or boiling point anything is in which we place our thermometer. We can divide the space between the two marks on the glass or frame as we please, and make a scale, as it is called, to measure the temperature. We can also find out how warm it is healthy to keep our rooms in winter and in summer, and what is the right temperature for a hot bath. Again, by seeing how far the mercury has fallen below the freezing point in winter time, we can judge how severe a frost there has been. In England it is never so cold as to make the mercury freeze; but in an arctic winter a mercury thermometer would be useless, and some other substance, which did not freeze so easily, would have to be used.

Heat, which produces the sensation of warmth to a greater or less degree, according to the nature of the substances through which it has to travel, reaches us in three ways. It is conducted to us by travelling through the substance of 


\section{STUDIES IN NATURE}

bodies, as it did through the iron poker; it is convected or carried to us by the movements of air or water; it is radiated from hot objects like the sun or a fire, and sent to us in invisible rays, some of which are turned into heat when they strike upon us.

When, as in our former experiment, we put a poker in the fire and let one end of it become red hot, the other end of it may be cold; but there will be some spot along the poker where it gets too hot to hold, even though that part is not in the fire itself. The heat is conducted along the poker from the fire. Some of the heat passes to the air around, some radiates away to all parts of the room, some travels along the poker. If we were to put two pokers, made of different substances, let us say iron and brass, in the fire close together, so that their ends got equally hot, and then waited for some time for the heat to travel, we should find ourselves able to hold them at different distances from the fire. One would have a better conducting power than the other, that is to say, it would let more heat pass along it.

We have already said that air expands when heated, and can show that this is true by our experiment with an india-rubber air-ball. Now when the free air which surrounds the earth touches parts of the ground which have been heated by the sun, some of it becomes warmer than the rest. The heated parts being lighter 


\section{HEAT}

will rise, and colder air must be drawn in from other regions to supply its place, just as we saw that colder air is drawn into a room in which a fire is making a draught up the chimney. In this way currents of air are kept up in the atmosphere, and this process of convection, as it is called, is the origin of the winds, which we shall have to study when considering the subject of weather.

The radiation of heat is a far more difficult matter to study; when examining it we should have to ask ourselves what heat is, and how it can travel across space to us from the sun, which clearly can neither conduct or convect its heat to us ; and also how it differs from light, which likewise travels across space from the sun, and perhaps also how it is connected with electricity, about which we know very little, but which can be obtained by means of heat, and from which we can in turn obtain heat. These are very difficult and deep matters, and are not thoroughly understood even by the wisest men; but they are very interesting, and we must try to get some ideas about them in another chapter. 


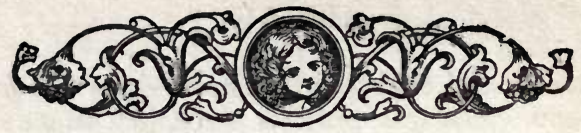

CHAPTER VI

\section{SOUND}

NATURE is full of sounds. If we set ourselves to listen attentively, we can almost always hear some noise in the world around us. Whether by day or night, there is a sound of something moving or something calling. As long as there is any movement of the air, we hear a rustling in the branches or leaves of the trees, a shivering in the grass, or a ripple on the water. Then there are all the noises that men make; voices talking far or near, carts and carriages moving along the roads, various machines at work; there is the twittering and singing of birds, the lowing of cattle, the hum of bees and other insects, the barking of dogs; we can hear endless sounds in every place we go to. There is no such thing as a quiet day. Nature is much too busy to be quiet, but she is also too busy to allow unnecessary noise, and every sound we hear has its reason and should tell us something. Even at night a country-side is hardly ever quiet; there are many creatures which seek their food by night, and others which call to each other only after the sun has set. 


\section{SOUND}

Perhaps in the heart of the country on a cold still night we might listen in vain for a sound; at any other season we shall not listen long.

Every one of these different sounds has its meaning, and will tell a great deal to people who take the trouble to understand. We all of us know a little about sound; we do not mistake the barking of a dog and the purring of a cat. We distinguish between a light cart going quickly along the road and a heavy waggon that is coming slowly. Sometimes the distant rumble of wheels is rather like the sound of running water, and a faint breath of wind in the poplar trees will make us believe it is raining, but we are not long deceived. Certain people can go a great deal further than this. They know the song and call of all the various birds; they can tell the footstep of one friend from that of another; they can distinguish between the bark of dogs, just as a shepherd is said to know the different bleating of his sheep. If they drive along a country lane at night they can often say under what trees they are passing, because the wind sings a different note for each new kind of foliage; and they will know what the road is made of from the sound of the horse's hoofs. .

It is worth while to go out into the country or into the street, or even to sit at home in a room, and to close our eyes, and then see how many different sorts of noise we can count, and think whether we know what is making them 


\section{STUDIES IN NATURE}

all. If there is any one of them we cannot account for, we can afterwards go and look, and we shall learn some very useful things in this way. We shall soon be able to tell how far off things are from us, and if they are moving towards us or away from us. We are often surprised to see how easily blind people move about, and to find out how much they know about the world. They do this very largely through their sense of hearing, which has to make up as far as possible for their want of sight. They hear a footstep, and can tell at once whether it is walking upstairs or downstairs or on the level ground. This tells them where the staircase is, and if they listen attentively they will hear how many steps there are, and will not have to ask or stumble when they themselves use the staircase. A blind man can often tell what is growing on the ground around him; he knows how the wind sounds in grass, through corn, or over heather.

It is a desirable thing for us all to have as full a use of our senses as possible. We believe this to be true in the case of eyesight, and if we cannot see pretty well we get spectacles to help us, for we use our eyes constantly, and expect to understand all we see. We are much more careless about our hearing. If we are deaf, we do indeed take a little trouble about our ears, but otherwise too many of us are content to go through life hearing only half 


\section{SOUND}

the sounds in the world, and understanding perhaps only a quarter of those that reach us. We may say that it would be of little use to us as long as we have eyes, but we must not forget that there are times when our eyes themselves are of very little use. In the dark, for instance, hearing will tell us much more than seeing, and if we have trained ourselves properly we should then rely on sound rather than sight.

Sound is a sensation which comes to us from a distance; not always from a great distance, and not always from the same distance. If we shut the window of our room, a sound from outside becomes much fainter. One day we can clearly hear the neighbouring church bells, another day they are quite indistinct. We may be kept awake one night by the noise of trains, and the next night forget that we are near a railway. Such differences as these are found to depend on the wind and the other conditions of the atmosphere, and show us, what indeed we probably already had realised, that sound is something which usually travels through the air. In order to find out the nature of this something, let us examine an object which is making a sound, say a gong or bell which has been struck, or a fiddle-string which has been played. If we touch one of these things lightly with the tips of our fingers we can feel it trembling, but almost at once the touch of the finger 


\section{STUDIES IN NATURE}

makes this trembling or vibration cease, and the sound then stops. Now let us think what effect this trembling of the object would have on the air around it. If we put our hand or a stick into water and move it rapidly to and fro, we see that a series of waves spreads out over the surface of the water on all sides. Here the waves are visible, and the effect of a vibrating body on the air which surrounds it is just the same, though we cannot see the waves which spread out through the transparent and invisible air. We cannot see the waves, but we can hear them, for these waves are sound.

Now that we have concluded that sounds are waves which usually travel through the air, there are many other things about them we want to know. For instance, how fast do the waves move? We may make experiments on this question in one of several ways. If a gun is fired late in the afternoon of a still day at a distance from us which we know, we can observe the time between seeing the flash and hearing the noise by looking at the seconds-hand of a watch. If the distance is half-a-mile, we shall find that the time is about two-and-a-half seconds. Thus sound travels through still air at the rate of about I Ioo feet in one second, about twelve times as fast as the quickest express train. In this way, too, we can gain some idea of the distance of a thunderstorm, for there is always an interval of a few moments 


\section{SOUND}

between seeing the flash of the lightning and hearing the noise of the thunder that accompanies it.

When the wind is blowing, we all know, or may easily observe, that sounds are heard much further in the direction of the wind than against it. The church bells or the railway train, which we mentioned before, are clearly heard when the wind blows from them to us, and not when it blows the other way. In order to explain this, people often say that sound is carried by the wind, and cannot travel against it. This shows the danger of hastily concluding that we understand things before we have considered them in the light of all the information we can get. We know that sound travels twelve times faster than an express train, and if we measure the speed of a strong wind we shall find that, in England at all events, it is rarely more than about half the speed of a train. Thus a fairly strong wind will only increase the speed of a sound that is travelling with it by a small part, and, if the sound is moving against it, it can only diminish it by the same amount. It follows that the effect of wind on the speed of sound is very slight, and we must look further for an explanation of the fact that sounds are heard much further with the wind than against it. When the wind blows it is clear that the lower parts of the great current of air, which strike the trees, houses, and other things on the 


\section{STUDIES IN NATURE}

surface of the ground, cannot move as fast as the upper air, where there is nothing to get in the way. Thus the top of a sound-wave moving with the wind travels a little quicker than the bottom; the front of the wave as it moves will lean forwards, and the sound will therefore constantly tend to move downwards; it will keep near the surface of the ground, and be audible to anyone on the ground at a great distance. But now let us imagine that the sound is moving against the wind; the top of the wave will now be kept back by the wind more than the bottom; the bottom of the sound-wave will therefore move fastest, and the wave bends backwards ; it leaves the surface of the ground, and advances into the upper regions of the air. To a person on the ground at a distance from the source, the sound may be quite inaudible, for most of the disturbance has gone over his head. We can confirm this explanation by listening for a distant sound travelling against the wind when we are on the top of a church tower, or in some other high position. We shall find that a distant sound which we can only just hear from the ground is much louder at the top of the tower. In fact, if the tower is high enough, or the wind is not too violent, from the top of the tower the sound is heard better against the wind than with it.

Besides the direction and strength of the wind, many other conditions of the atmosphere 


\section{SOUND}

affect the distance to which a sound can be heard. Anything which tends to stir up the air and make it less uniform, such as little currents of warm rising air, help to prevent the passage of the sound waves; just as glass, which is usually transparent, will not let light through as easily when it is scratched or powdered up. Again, a very violent wind is full of eddies and irregular movements, and soon makes a sound die away even in the direction of the wind. In a fog the air is usually still, and as the sunlight does not reach the ground there is no local heating. This is a state of the air in which it is generally uniform, and it is well known to sailors that sounds can often be heard distinctly for long distances in foggy weather; indeed, it is not difficult to observe this for ourselves.

We have seen that sounds are carried by waves or vibrations moving through the air. If the source vibrates very quickly, the sound it gives out is high and shrill; if it vibrates more slowly, the sound is deeper and lower in tone. There are many things in Nature which create these vibrations. Our voices are made for this purpose ; they set up vibrations of various times and amplitudes, and so produce the words and notes of our speech and song. A blow will cause the particles of the objects that strike, or are struck, to vibrate or move very rapidly, and these movements are passed on as soundwaves to the air through which they travel till 


\section{STUDIES IN NATURE}

they die away. Our ears are arranged to take in these vibrations and send news of them to the brain, by means of which we understand them. Animals, as we know, also have ears and listen attentively; a dog will sometimes seem to hear a noise before the cause has come near enough for it to be sufficiently loud for us to hear. In the same way, dogs and other animals can distinguish smells which we cannot notice at all. Men who spend their lives out of doors in the country, and especially those races of men who are out of reach of our civilisation, are often found to have powers of hearing, smelling, and even seeing which are greater than those of town-bred people. This is probably because they depend more on these senses for knowledge about the movements of other men, whether friend or enemy, and of animals, whether dangerous or useful as food. It seems likely that if we do not use our senses, we gradually lose the power to do so, and this is a very good reason for trying to increase our field of observation in every way we can.

Sound, as we should naturally suppose, travels far more easily when there are not many obstacles in its way to turn it aside and otherwise disturb its course. Trees, walls, and hills all prevent its free passage. If we listen to a cart which is being driven down a road, we can often tell when it is going between high banks, through a wood, across an open space, or past 


\section{SOUND}

buildings ; and in the same way we can tell from the noise of a railway train when it is going through a deep cutting, into a tunnel, or out on to an open embankment. Even if we did not know the country at all, and were sitting there for the first time on a dark evening, we should learn a great deal about the character of the neighbourhood by listening attentively to the sounds, and thinking about their direction and their meaning.

We sometimes come across one curious and rather misleading effect of sound, which requires a little consideration, and that is an echo. We make a sound, probably with our faces turned to a wall or wood, and very shortly the sound comes back to us; it is, as it were, reflected to us, just as a looking-glass will reflect our faces. The sound-waves when they reach the wall or clump of trees strike against them and are turned back in an orderly fashion. We can actually see this happen to waves of a different sort. Let us drop a pebble in a basin of water or a quiet pool; it sets up waves in the water which travel out on all sides to the edge, against which they strike and rebound and begin to travel back again. We do not often hear an echo, because we have to choose the position in which we stand very carefully; as we know, to see ourselves in the looking-glass we must stand in front of it, and, moreover, not everything in front of which we stand will act as a 


\section{STUDIES IN NATURE}

looking-glass; it is no good to stand in front of a wooden door or muslin curtain.

By means of an echo we may make another attempt to find the speed at which sound travels. We can generally tell what object is sending the air waves back to us, and if we measure how far away it is, and see by the seconds-hand of a watch how long a sound takes to get there and back, we can calculate the speed. 


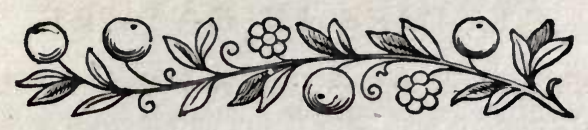

\section{CHAPTER VII}

\section{LIGHT AND COLOUR}

IT is easy to see that most of our light comes to us from the sun, and that light in some way brings colour. It is very difficult to say how light comes, what light is, and in what way it creates colour; and even when we have found answers to all these questions we still do not in the least know why it comes. It is a common mistake to think that if we know how a thing happens, we know the reason why it happens. Men of science give up their lives to try to discover the methods by which Nature works, and we are following a little of the way after them; but even they know nothing about the First Cause which creates these wonderful effects we are trying to trace out.

Light comes to us from the sun, and when the evening sets in, and the part of the earth we are on turns away from the sun, it begins to shine on other parts of the earth, making daylight for them. It is quite true that it is always midday somewhere on this globe of ours, as it keeps turning round and round; and quite true also that somewhere it is always midnight. The 


\section{STUDIES IN NATURE}

sun does not stop shining, even though it does not shine on us. But if the sun is always shining, surely the heavens, across which it shines, ought always to be bright? We see the stars at night, which are much farther away than the sun, and as the sun shines always, on all sides of itself, and not only just in that particular spot of the heavens where our earth happens to be, we surely ought to see the light from the sun going out in all directions. We see the light from a lamp or candle brightening other objects in the room, even if we put a screen or hold a book between the lamp and our eyes. But the heavens are quite dark at night except for the stars, and sometimes for the moon. If we think about these two things a little longer, we shall perceive that we can see different objects in two ways. Either the objects themselves are sending out light, as are the sun or a lamp, or else the light from such a source is falling on them and then reaching our eyes. Again, we find that if a screen be held between us and any object we cannot see the object. From this we conclude that the light which previously made it visible travelled in straight lines. A luminous source is only visible when there is an uninterrupted straight line from it to our eyes, and we can only see another object when the way is clear between it and ourselves and light shines on it.

Light has different colours; the light of a 


\section{LIGHT AND COLOUR}

lamp is yellower than that of the sun, while glowing coal shines red. Even when the light coming from the source is white, we know that different things on which it falls have different colours to our eyes. Light, it is clear, brings us colour, and the world would be a very dull place without colour. The grass is green, the sky is blue, a house is red, yellow or grey; this all seems quite simple. But as usual, when we begin to think a little more, we find that things are not so simple as we are at first sight inclined to believe. The sky is not blue at sunset, at any rate it is not all blue; it is quite as often grey as blue at sunrise. The grass is green in the day-time, but it may seem black at night, and almost purple at sunset. Hills may look grey at sunrise, green at mid-day, blue in the evening, and brown and green if we walk up to them. What colour are they really? I myself have twice seen, once in Egypt and once in Norway, a range of hills that were not very far off, look as crimson as any rose. A haystack is usually yellow or brown; in the glow of a sunset I have seen one look purple, and have also seen pictures in which artists have had the courage and sense to paint them so.

Perhaps we may begin to think that colour is a very uncertain thing; but if a rose is red one day when seen near at hand in ordinary day-light, we are sure that it will be red the next day, and pretty sure that the same rose-bush will have red 


\section{STUDIES IN NATURE}

flowers next year. When illuminated by white light the grass underfoot is always green, and the few occasions when it is not are due to some change in the light. This is all quite true, but we have got back to the fact we started from, that colour is an effect of light; that light, as we said, brings us colour. But have we not learned a little more on our way? There is some property or nature of the rose which makes it red, of the grass to make it green; and as for the occasion when these things are not the colours we expect them to be, we can account for that to some degree. They do not occur in broad daylight, but they happen at sunset or sunrise, when the light is no longer ordinary white light, but may be any sort of colour, from red and yellow to blue and purple. Here we have indeed arrived at the truth, but it is not the whole truth, and we must seek deeper to explain some of the colours of things seen from a distance. Now distant hills look blue in daylight, and the farther away we are the bluer they become. What has changed? The light falling on them must be the same, but we are farther from them, and the light reflected from them to us, by which they are visible, has gone across a longer path through the air. It is the passage through air which makes the light from distant objects seem bluer.

Leaving the effects of distance and those of changes in the nature of the light, let us con- 


\section{LIGHT AND COLOUR}

sider the usual colours of near objects seen in white daylight, and ask why a rose is red, and why the grass is green. How does the rose change the white light of the sun into red? We cannot find an answer to this question till we know more about the nature of white light. Is a beam of white light all one kind of thing, or does it contain different kinds of light, some of which may be treated in different ways from others by the bodies on which they fall ? An experiment we may all of us make throws light on this problem. Glass is a colourless substance, which usually lets white light through it unchanged. Yet, if we take a piece of glass with a sharp wedge-like edge, and hold it up to the light, bright colours are seen. Water too shows the same effect. In large masses it is colourless, or nearly so, and a glass full of water lets the light of the window pass through it and still looks white. When divided into fine spray or rain, however, the same colours that we found with the glass wedge may sometimes be seen. When water falls in spray over rocks, or when a shower has passed over us, and the sun is shining from behind us, some of the light passing through the drops will be bent back to our eyes and form a rainbow. Now all these things are easily explained if we imagine that what our eyes see as white light is really not simple but complex, made up in a certain balanced proportion of coloured lights, which, when perceived 


\section{STUDIES IN NATURE}

by our eyes, blend into a sort of chord of light and produce the sensation which we call white. This explanation not only agrees with the facts we have given, but will help us to understand many others, which have been studied by men of science, and it is universally accepted as the truth.

We may now follow further our inquiry into the colours of the natural objects which we see around us. If we put a red glass in front of a lamp, the light which comes through is red, not because anything new has been added to the white, but because all the colours of the rainbow other than red have been taken away and absorbed by the glass. The violet, blue, green, yellow, and orange cannot get through, and we are left with the red rays only, which pass freely through the glass and reach the eye. At first sight this does not seem to help us in understanding the colours of certain things, such as grass, which we see, not by the light passing through them, but by receiving light in the eye which has been reflected or sent back from them. But if we take a very thin layer of any of the coloured things we have mentioned, such as a thin strip torn from the petal of a rose, or from a green leaf, we shall find that some light is able to get through them. Even a substance a close and thick as gold lets through a little light when beaten out very thin. When light falls on a coloured object, let us say a leaf, we 


\section{LIGHT AND COLOUR}

may trace out what happens to it in the following way: The white light enters a very short distance into the leaf, but sooner or later gets turned back by irregularities and obstacles within. In its course it passes through a layer of matter which takes up certain of the rays of white light more than others, and keeps them behind inside, so that the light which finally comes out and reaches the eye has lost some of its parts. The balance is upset, and this light no longer looks white; it has the colour of those rays which have not been taken away.

When we go further, and ask how these bodies take away and absorb some of the coloured rays of white light, we are led into much deeper questions-questions over which men have puzzled for many centuries. The conclusion they have come to depends on evidence that we may some day study as a branch of physical science. We shall find that the only satisfactory explanation is to regard light, like sound, as a kind of wave motion. The particles of coloured bodies can move, as it were, in tune with certain kinds of waves more freely than with others, and so the energy of those waves is absorbed by the particles, and the light passes on without them.

If light consists of waves, there must be some substance in which the waves can travel. We have seen waves travelling in water; we have found waves that travel in air. The sub- 


\section{STUDIES IN NATURE}

stance in which light travels cannot be air, for light passes from the sun to the earth through regions far beyond the reach of our atmosphere, which is indeed but a film over the face of the globe. Hence we believe that space is filled with something about which we still know very little, except that it can transmit waves, which if they are very short affect our eyes as light, and if they are very long can affect electrical instruments, and be used in wireless telegraphy. This something is now generally called 'ether.'

The best way to begin our study of waves is to watch those that are visible, such as the waves that cross the surface of the sea, or any other sheet of water. If we watch a little piece of floating wood, or a boat, which is lying out at rest, we shall see that the particles of water do not move it forwards, they only move it about near its original position; it rises and falls as the waves pass. True waves are pulsations or throbbings in the ocean, they seem to beat time, they do not in the end move the water either onwards or backwards. The waves of the ocean are not all of the same size; there is not always the same distance between the top or crest of one wave and the crest of the next. The waves of sound too are of different lengths, the short quick ones which strike our ears many times a second produce high, shrill sounds, while the longer waves, fewer of which arrive during a second of time, give low deep tones. In the 


\section{LIGHT AND COLOUR}

case of light, the difference in the length of the waves, or more truly the difference in the rate at which they vibrate, causes the difference in colour-red light consists of longer waves, blue light of shorter ones. Although waves of all lengths seem to travel at the same rate through the free ether of space, when they enter glass or water their speed is reduced by different amounts, the blue waves are kept back more than the red ones. They are thus separated from each other, and the different colours may come out of the glass or water in different directions, showing us the colours of the rainbow.

As we found out, leaves, flowers, animals, and other natural objects seem to choose out certain of these waves more freely than others, to such an extent that the light which comes back from them has been deprived of some of its parts. We may well ask what becomes of these absorbed waves? Now we know that a body placed in the sun's rays gets hot, and if we are observant we ought to know that a black body gets hotter than a white one. At any rate, we all put on white dresses and light clothes in summer-time, which shows that we act on this principle even if we have never troubled to think about it. But we now understand that a white body is one that sends back all the parts of the white light, while the black body takes them all in. We gather from this, then, that the rays which are absorbed are turned somehow 


\section{STUDIES IN NATURE}

into heat, and their energy and strength goes to raise the temperature of the absorbing body. When the great ocean waves reach some obstacle like the coast or islands of rock, we find foam and confusion, breakers and noise; in the same way, when the waves of radiation strike the particles of a body, those particles destroy some of the ether waves, and are themselves set into the mode of vibration which we know as heat.

We have not yet finished the history of these ether waves, for not quite all the energy of the absorbed waves is changed into heat. In the chapter on Air, we saw that under the influence of sunlight, green plants were able to decompose carbonic acid and liberate oxygen. To do this also requires energy, which the plants obtain from the sun's radiation. Again, we know that when falling on certain kinds of sensitive surfaces, light is able to produce obscure chemical changes which result in a photograph. Here again, some of the absorbed rays are used in other ways than merely to heat the absorbing body. The light that enters our eyes, and through them gives impressions of shape, colour, and shade to our brains, must have a very complicated history, one that has not yet been traced out fully. We cannot follow up all these different possibilities here. We must be content for the present to have learned a little about the nature of this wonderful wave-motion. 


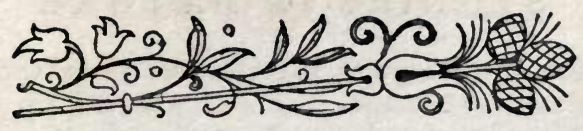

CHAPTER VIII

THE WEATHER

Besides the regular changes in the seasons, which give us the warmth of summer and the cold of winter in the course of each year, there are other slighter changes, from warm days to cold days even in the same season. Sometimes, too, it rains at frequent intervals for many days together; at other times a long drought turns the lawns and pasture fields brown, and causes the water-supply of towns and villages to fail. In this chapter we are going to study these changes in the weather, and try to find out some reason for them.

If we carefully watch the rainy days throughout a year, we shall find that in the British Islands most of them come when the wind is from the south, south-west, or west. It is true that rain occasionally falls when the wind is in other directions, but this happens much less often. As a general rule, then, we find that a south, south-west, or west wind is likely to bring rain, while dry weather is more probable if the wind is in the north, north-east, or east. Now let us look at a map of Europe. To the west 


\section{STUDIES IN NATURE}

of the land lie great stretches of ocean, and to the south-west the ocean is warmed by the southern sun, and also by a slow but mighty current in the water, which comes from the tropical seas near the Gulf of Mexico, and is called the Gulf-stream. We already know that warm water tends to evaporate and mix with the air as invisible vapour. The winds which blow over the warm ocean will therefore take up a large amount of water-vapour, and when they reach our colder regions the vapour may condense as rain, just as drops of water condense on the inside of our bed-room window when it is chilled by the outside air on a cold night. It is but natural then that south-west winds should often bring rain. To the east and north-east of Britain lie large tracts of land, and very little sea until we reach the frozen Arctic Ocean. Winds passing over the vast plains of Russia and central Europe can absorb no moisture, and when they reach our shores are usually very dry.

Besides noticing the connection between rainy days and the direction of the wind, let us also think which winds bring hot and which bring cold weather. Now we shall find that there is a difference in this according to the season of the year. In winter the north-east winds usually bring cold, or even frost, while south-west winds accompany mild and open weather. In summer a north-east wind, if it is not too strong, means hot, scorching sun, with 


\section{THE WEATHER}

great heat, while a south-west wind often brings cool refreshing showers. In order to understand this fully we must again look at our map, and must also know what is not always told us on maps - that is, which places are hot, and which cold, both in summer and winter. In winter the British Islands are much warmer than places in the east of Europe, or in North America, which are equally far north; and if we seek for reasons, we shall find that the temperature of the water of the sea which surrounds our islands is much higher than that opposite to it along the North American shore on the other side of the Atlantic. This suggests that the neighbourhood of the sea makes a place warmer in winter, and that the milder climate which we enjoy is due to the unusual warmth of the sea which is near us. Here again we remember about the Gulf-stream, of which we have heard when studying geography. The warm water brought from the tropical regions of the Gulf of Mexico by that great ocean current warms the air which lies over it, and gives a mild genial climate to the shores by which it passes. The stream flows along the west coast of Ireland and Scotland and passes on to Norway; when a south-west wind blows with it, while calms or east winds prevail over the south of Europe, we may even find that the temperature may actually be higher at the North Cape of Norway than it is in south central Europe. In winter, 


\section{STUDIES IN NATURE}

then, it is natural that a south-west wind should bring mild weather. It is equally natural that a north-east wind, coming from the frozen plains of Russia, should bring cold and frost.

As yet we have said nothing about the effect of the sun in England; during the winter season the temperature does not depend much on the sunshine. The sun is low in the sky, and the direct effect of his rays in heating the ground is very small. The result of the changes in the wind, and the differences produced by its coming from warm moist regions and from cold dry ones, are so much greater than any effect of more or less direct sunshine, that the influence of the sun's direct heat may be neglected. In the middle of a great continent, however, this is not so, and in central Europe or Asia the absence of much sun in winter produces extreme cold; for there are no warm oceanic regions near to warm the winds coming from any direction.

In summer the sun is much higher in the heavens, and the land of our islands gets heated by its direct rays. Thus a clear sky in summer usually means heat, while in winter it often brings frost, since, as we have seen, the warmth can then escape into space. On large continental areas this effect is much increased; the influence of the sun is not masked by the influence of neighbouring oceans, and clear weather in winter means extreme cold, and in summer extreme heat. Thus the dry north-east winds 


\section{THE WEATHER}

from the plains of Europe in summer are very hot, and, the sky being clear, the ground in England is further heated by the direct rays of the sun. On the other hand, although the water of the ocean absorbs much less of the sun's heat in summer than the earth's surface, it radiates much less of it in winter. Moreover, by movements in the water, the heat thus absorbed is more evenly distributed in the sea than in the ground, and the capacity for heat of such a vast volume of water being enormous, the ocean acts as a great reservoir of heat to supply the land. For all these reasons the sea is warmer in winter and cooler in summer than the land. In summer, then, the south-west winds may actually come from cooler regions than the north-east winds, and, moreover, the sky with a south-west wind being often cloudy, there is very little heat obtained by the ground from the direct rays of the sun.

Since the invention of the electric telegraph, we have been able to learn much more about the weather, for it is now possible to find out what is going on at many places at once, and to know how far the wind or weather is the same with us as with our neighbours. In London, and in the capital cities of most other civilised lands, there are offices which exist for the purpose of collecting information about the weather. Every morning in the Times newspaper, and in some others, there is printed a small map of the 


\section{STUDIES IN NATURE}

west of Europe, showing what kind of weather there was at many different places at six o'clock the previous evening. On this map little arrows are drawn to show the direction and strength of the wind, and the first thing we notice is that the wind is not blowing from the same quarter at every place; in fact, we shall generally see that it is blowing round and round in great circles. In the south-east of England the wind may be from the south-west, over the North Sea it may be south-easterly, near the Orkneys it may come from the east, off the west coast of Ireland it may blow from the north, while it may pass up the Channel from the west. In such a circular swirl as this, the wind blows round the circle in the opposite direction to the movement of the hands of a clock. Sometimes, however, the circle of wind blows round the other way, following the clock hands. These two kinds of wind-movement are very important if we want to study our English weather, and we must try to find out more about them.

We probably all know what is meant by a barometer or weather-glass. It consists of a long tube of glass, closed at one end and open at the other. The tube is filled with the liquid metal mercury or quicksilver, a finger is placed over the top, and the tube is then turned upside down, and placed in a little vessel also filled with mercury. The mercury in the tube falls, but owing to the pressure of the atmosphere on the 


\section{THE WEATHER}

surface of the liquid in the outer vessel, it does not all fall out of the tube. We shall find that inside the tube the mercury stands about thirty inches higher than in the little vessel outside. If we fix a scale to measure this height, we shall see that the reading varies from day to day, and in this way we observe something which depends on the pressure of the atmosphere. Now let us look again at the little map in the newspaper. Besides the arrows showing the direction of the wind, are some dotted lines, marked $29^{\circ} 9,30^{\circ} \mathrm{I}, 30^{\circ} 3$, and so on. These lines are drawn through all places at which the barometer stands at the same height, the figures showing the number of inches between the level of the mercury inside and outside the tube of the instrument. Now these heights measure the pressure of the atmosphere, and therefore by looking at the map we can see at once how the pressure of the atmosphere, that is, the weight of the air, varied over the west of Europe at six o'clock the previous evening.

If we look at these barometer lines when the wind is blowing in a circle in the opposite direction to the hands of a clock, we shall see that the pressure is lowest towards the centre, and higher the further we go outwards. This circular swirl with a low-pressure centre is called a 'cyclone.' On the other hand, when the winds are circulating in the clockwise direction, the area of greatest pressure lies inside the circles 


\section{STUDIES IN NATURE}

near their centre, and the further we go outwards the lower the pressure becomes. The state of the atmosphere is then called an 'anticyclone.' Now, where the pressure is high, the air will be forced away towards the regions where it is low, and the new air will descend from above to take its place. Therefore over the high-pressure area of an anti-cyclone a column of air is constantly descending from the upper atmosphere, and spreading outwards over the surface of the earth.

But why should the wind blow in circles? Let us remember that the earth is like a great top, always spinning on its axis, and perhaps this will help us to find an explanation. If an orange be placed on the table, and turned round as it stands, we see that a point near the top or the bottom of the orange has not got so far round to go as a point near the middle of the orange. So with the earth. A point nearer the north or south pole has not so far to travel each day as has a point further away from the poles. Thus the wind which blows outwards towards the south from the centre of an anticyclone lying over north Europe, passes over points on the earth which are moving faster and faster the farther the wind goes. The wind will therefore meet the ground as it revolves, and will seem to be travelling in the opposite direction. Now the earth revolves from west to east, and thus the wind gets a drift from east 


\section{THE WEATHER}

to west. Instead of moving straight towards the south as a north wind, it will move towards the south-west, and thus become a north-east wind. On the other hand, the air which flows away from the centre of the anti-cyclone towards the north, passes over regions of the earth which are travelling less fast in the daily rotation than the places whence the air came. The air then seems to be coming in the same direction in which the earth revolves, and the south wind becomes a south-west wind. In this way the whole of the air spreading outwards gets a clockwise swirl, and the observed movements are explained.

We still have to consider why an anti-cyclone should permanently exist over the continent of Europe and Asia during the winter months. We have seen that these vast stretches of land get very cold in the winter. The air lying over them gets cold likewise, and therefore, as we know, becomes heavier than the warmer air in other places. It therefore tends to sink and flow outwards over the ground, giving rise to a high-pressure system and the arrangement of winds we have described. The anti-cyclones that are observed over the British Isles are of two kinds. They may be small and local, when they will probably soon disappear, or they may be parts of the great permanent continental anticyclone, when we may look for a long spell of dry settled weather, with north-east or easterly winds. 


\section{STUDIES IN NATURE}

In our country we are more often under the influence of a cyclone than of an anti-cyclone, and in a cyclone the winds are spinning round in the opposite direction. If we look again at the telegraphic reports, we shall find that the centre of a cyclone is an area of low pressure. It follows that air is forced inwards from other places where the pressure is higher, and a column of rising air must exist at the centre. The cyclone is just like the movement of water in a basin, when it is allowed to run away through a hole in the bottom and given a lefthanded swirling motion; or rather, would be like that water if we imagine the basin turned upside down, so that the water was drawn out of the basin at the top, and was still made to revolve in the counter-clockwise direction. Moreover, just as the water in the basin swirls faster and faster the nearer it gets to the centre, so the strength of the wind increases towards the centre of the cyclone, till near its core there may be a violent gale. The other most important thing to observe is that the cyclone itself moves as a whole. In England, for some reason not yet clearly understood, the path of most cyclones is from south-west to north-east, and the core of the cyclone usually passes over the north of England or Scotland.

From what we have said about the circulation of the winds, it will be clear that as the cyclone moves over us the wind must change. If, as is 


\section{THE WEATHER}

usual in the south of England, the core of the cyclone passes to the north of us, while it approaches, the wind will blow from the southwest. When it travels on, the wind veers first to the west, and finally to the north-west as the cyclone passes away, and the weather becomes finer and dryer. If the core of the cyclone is near us, the wind and the changes in the wind are much more violent, and gales may blow from almost all points of the compass within a few hours.

There are other reasons besides the influence of the accompanying winds which usually make a cyclone bring wet weather, while an anticyclone is often responsible for drought. In an anti-cyclone the air, as we have seen, is falling from the upper regions of the atmosphere, where, as those know who climb mountains, it is very cold. The cold air can hold but little water in suspension, and is therefore very dry. As it falls it is compressed, and therefore is slightly warmed, though it probably is still colder than the air which was already below it. When it is warmed it is capable of taking up more water ; this it does, and, taking water from everything it can, produces very drying winds. In a cyclone the reverse occurs. The warm air, which is saturated with moisture from the ocean, is sucked inwards to the centre of the cyclone with a constantly increasing spin, and then whirled upwards. As it rises it expands and therefore 


\section{STUDIES IN NATURE}

cools ; it cannot hold all the water there is in it, and some of this water soon descends as rain.

We have now traced the chief features of the weather of the British Islands. We principally feel the effects of two different kinds of weather which succeed each other at irregular intervals. The cyclonic systems, usually arising somewhere over the Atlantic Ocean, generally bring south-west winds and rain, while the continental anti-cyclones, which sometimes extend over us, bring dry easterly or north-easterly winds or calm, dry weather. 
PART II 



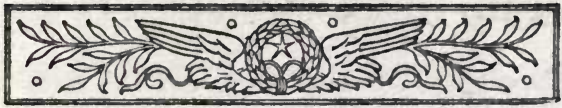

\section{CHAPTER IX.}

\section{THE COUNTRY AND ITS NAMES}

LET us suppose that we are going for the first time in our lives into a new country neighbourhood which we have never seen before, about which we know as yet nothing, and nevertheless to a place where we shall probable stay for some little time and want to feel ourselves at home as soon as possible. Now some people call the country dull, and tell us there is nothing worth seeing there and nothing to be interested in, and have perhaps made us feel that it is no use in trying to be happy in such a stupid place, for it would be a stupid place if all that they told us were true. But we must be careful when we are told that something or somebody is dull and stupid; it often only means that the person who is speaking to us is not very clever himself, and does not know what is really interesting, and has not found out the way to make life worth living.

I think the first thing we should want to know about this country we had come into would be its name, and after that the names of its towns, villages, rivers, and later on, the names of its inhabitants who were to be our 


\section{STUDIES IN NATURE}

neighbours, their occupations and the names of their houses. But, perhaps, someone will say, this may be useful to us, but it is not very interesting. When we have got a list of all these names we don't know anything more about the country or what it is like. People are very apt to forget that every name has a meaning, and was given for some particular reason. We cannot, it is true, always at once understand the meaning, or find out the reason it was given, because names, like all other words, get altered as they are used by generations of men. This was especially the case in the days before reading and writing were much studied, and printed books, papers, and maps were rarely to be seen. Moreover, other languages besides English have been and are spoken in the British Isles, and some of the names of places belong to languages which are foreign to us. In this case again, it is we who are at a loss, not the names that have nothing to tell us.

We ourselves often give names to the places around us when they have not any, or we do not know what they are, in just the same way that our forefathers gave to villages, towns, and rivers the names which we still use. We speak of Thompson's Lane, Haigh's Corner, the Ashfield, the Red River, the Church Farm, the Bull Coppice, by which we mean the lane to or past Thompson's house, the corner near Mr. Haigh, the field where the ash tree is, the river where 


\section{THE COUNTRY \& ITS NAMES}

the water or the banks are red, the farm near the church, the coppice or enclosure where the bull is kept, and we can all of us probably think of a great many others, hardly as yet to be called real names, but which serve very well to distinguish the places. Now if we look at the names all up and down a map of England, we shall soon see that many of them have been given in much the same way as those we have written down above, and do tell us something about the place or its history.

Let us consider a few of these. How many places for instance can we think of, or find, with names ending in 'ford'? There are Bradford, Oxford, Bedford, Stamford, and many others. In Cambridgeshire alone, not more than five miles away from each other, we find Shelford, Stapleford, Pampisford, Whittlesford, which point out to us all the different places where the roads cross the river, and where people have gathered themselves together to live. Moreover, as these places, where the river is shallow enough to ford or walk through, are so near together, we may fairly assume that the river is not very big or deep. There would probably not be many fords on a big river; we should expect to hear of ferries, boats, and bridges instead. And so we do. We find Queensferry, Rockferry, Earlsferry, Boat of Garten, Cambridge, Staleybridge, Bridgenorth, and hosts of other similar names scattered over the country. Then there are 


\section{STUDIES IN NATURE}

such names as Norton, Eaton, Sutton, Weston, Milton, which mean the North ton (little town or settlement), the South ton, the East ton, the West ton, the Middle ton or sometimes the Mill ton. We can find out where an old street or Roman 'via strata' (paved way) crossed the country, and where the Roman camps or settlements called 'castra' were placed. There are several places called Stratford, which shew where one of these streets crossed a river; there is Stratford-upon-Avon, there is Stratford just east of London, Fenny Stratford and Stony Stratford in Buckinghamshire. As for the 'castra,' or chesters, as we more frequently call them now, we can think of Manchester, Chichester, Lancaster, Leicester, Colchester, Castor, Caister, Chesterfield, Exeter (Exechester), and many others ; they are to be found in every part of England. Following the Roman 'castra' we get the castles of the feudal time of English history; there are several Newcastles, there are also Oldcastle, Bewcastle, Castle Acre, Castle Howard, Castle Cary. Some names are quite easy to understand. We shall have no difficulty at all about Whitehaven, Coldstream, Redditch, Seven Oaks, and Blackwater. Nearly all our rivers give names to places on their banks or at their mouths. We find Alnwick and Alnmouth, Exeter and Exmouth, Tweedmouth, Yarmouth, Weymouth, Falmouth. Sometimes the church, often called in the north of England, kirk, and 


\section{THE COUNTRY \& ITS NAMES}

in the south, minster, makes a village noteworthy; we then get such names as Ashchurch, Whitchurch (or Whitechurch), Upchurch, Selkirk, Ormskirk, Kirkoswald, Westminster, Warminster, Leominster, and Axminster. What an expressive name for instance is Kirkby Lonsdale! We learn at once that it is a 'by' or 'settlement' with a church in the dale or valley of the river Lune. At Stamford Bridge there must be a river which was once to be forded, and later on had a bridge built over it. Sometimes we get bits of history attached to names; who owned them, built them, or what happened there. As examples of names of this sort we have King's Lynn, Newton Abbot, Bishop Stortford, Abbotsford, Bury St. Edmunds, Charing Cross, Battle Abbey. Another class of names speaks of markets and fairs, another of ports and harbours, a third of hills and dales. A very great many tell us the names of the first English settlers who established their 'tons,' 'bys,' ' hams' (homes), all over the country; indeed, the largest proportion of names in England seem to have been given by the English, Danish, and Norse settlers, and the ones that were in use before have very largely been forgotten.

The names of people are not now as interesting as the names of places. We have surnames which go on from father to son, and do not change with our trade or home as they 


\section{STUDIES IN NATURE}

used to do. In old days people spoke of Tom the Tailor, Dick the Cook, Will the Farmer, John the Hunter, and we go on calling ourselves Taylors, Cooks, Farmers, and Hunters, although neither we nor our fathers follow these occupations any longer. Again, Tom may have been John's son, Dick, Will's son, Will, Nell's son, and we get the names of Johnson, Wilson, Nelson. There would be Tom of the Hill, George of the Heath, Sam from the New Ton, Jack of Huntingdon, Hugh the Fleming. All our surnames had once their meaning, and can even yet tell us a good deal about the places where our forefathers lived and the trades by which they earned their living. We all of us know that John Gilpin, in the celebrated piece of poetry, was a linen draper; but which of us can say now what was the profession of his friend the Callendar, from whom he borrowed his horse? Such names as Cartwright, Wheelwright, Chapman, Smith, carry us back to the days when every village had its own maker of carts and wheels, its travelling merchant, or pedlar as we might call him now, and its smiths, blacksmiths, whitesmiths, locksmiths.

If then we were to come into this new country of which we were speaking in the beginning of our chapter, we should know something about it when we had found out the names. We might begin by getting a map of the district and looking over it carefully, and then, when we 


\section{THE COUNTRY \& ITS NAMES}

had made up our minds what to expect, go out and see if we were right, and find out as much more as we could. Or we might first study the country itself carefully, find out where the roads went to and came from, what were the names of the rivers and villages, and how far apart they were, and then go home and try to make a map for ourselves, adding a little bit more to it each time we found out a fresh place or a new name. 


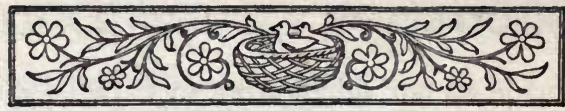

\section{CHAPTER $\mathrm{X}$}

\section{ROADS}

ROADS of some sort must have existed for many thousand years. We cannot imagine ourselves without paths. As soon as there were any inhabitants at all in a country there must have been roads, although perhaps they were only tracks across the plains and forests to the huts and caves where the folk of those days hid themselves away. Even animals make their roads; there are sheep-tracks on the downs and fells, there are rabbit-runs through walls and hedges, even the little ants make tiny tracks in our lawns and paths as they run ceaselessly to and fro to their homes. Roads like these, that grow up naturally, are never straight; they are quite different to the railway lines, or the roads and streets that are laid out and made by engineers and builders. They bend to one side or another, perhaps to avoid some fallen tree or big stone which has long since disappeared; they will go up to a place where a farmhouse or inn once stood, and down towards the river where there has been a ford or a mill. They will sometimes go right out on to high open ground, as though to command a view of 


\section{ROA DS}

the whole country-side and save the traveller from sudden attack. In another place they will creep under a hill and hide themselves between high banks, so that the wayfarer could pass along them unseen. There are wide roads, narrow roads, steep roads, and hidden roads, but we never come across a straight road that has been made under natural circumstances. If we look at a path which is to-day being worn across a field, or an expanse of freshly fallen snow, we shall see that it is not straight; people take advantage of the little rises and falls in the ground, they avoid a stone, a puddle or a flower. Whatever the reason may be, no natural road is straight.

Let us think for a few minutes how the different kinds of roads must have arisen. First of all must have come tracks where men could walk one at a time. Then these tracks would become wider as they were used to ride or to drive cattle and sheep along. The invention of wheels would again alter our roads, for even the rough carts of our ancestors would require firmer surfaces and broader ways than a horseman or a flock of sheep. When the Romans came with their chariots and organised armies and their luxurious civilisation, they made, or in some cases re-made, the great roads which still run straight across the country in all directions, and paved them so well that the work they did nearly two thousand years ago is still 


\section{STUDIES IN NATURE}

to be seen in places. The Romans were the greatest road-builders the world has ever known, and road-building and bridge-making were honourable professions in their eyes.

After they left the country, the roads were not properly kept up, and gradually fell out of repair, but they were still used, and many centuries later we find the same roads carrying the traffic of the country. As the land became more settled and fields were enclosed, hedges and walls were placed along the roads also, and sometimes broad margins of grass were left at the sides for horsemen to ride on, and to pasture the herds and flocks that might be driven along them. Then came the mail coaches and travelling chaises, and an increase in the number of inns and posting-houses along the highways. The railways in the middle of the nineteenth century put an end for a time to the long distance traffic on the roads, and they again fell somewhat into disrepair, until bicycles and motor-cars seem likely once more to bring them into more general use.

This, in a few words, is probably the history of many of our great roads. We can find them on a map stretching across England from east to west, from north to south. There is one, the great North road, running from London to York and on into Scotland; there is another from London to Bath and on to Exeter; another from London to Dover through Canterbury; a 


\section{ROADS}

fourth joined together Bath and Lincoln, a fifth Bath and Norwich; Chester, Manchester and York were in communication, and also Manchester, Lancaster, and Carlisle. Long before railways were thought of, these grand old roads brought together traffic from all parts of the country, and the railways for the most part have been content to follow alongside them.

We still find roads of all the different sorts we have mentioned in England at this present day. There are narrow paths across fields, through woods and over downs. There are bridle-paths along which we may ride; and very useful they were in old days when merchandise was largely carried in packs or bales strapped on to the backs of horses or mules, and when riding and walking were the chief methods of getting about the country. There are narrow lanes between farms and villages, and roads that are little better than carting-tracks, which lead to out-of-the-way fields and cottages. Then there are other wider roads kept up in each district, along which we can comfortably drive, and finally there are the great high roads of which we have already spoken.

After a path or road has been freely used for a certain number of years it cannot again be closed up; a right-of-way has been created through the land. Rights-of-way sometimes exist for particular purposes; such as a right to cross certain fields to go to church. A path 


\section{STUDIES IN NATURE}

of this sort is called a church-way. In old times there were special roads along which people might ride when they were going pilgrimages to the shrines of saints and other holy men. Such a one existed between Winchester and Canterbury. These have fallen into disuse now, and can hardly be traced. There were also pack-ways and bridle-paths for horsemen. In the days when a considerable part of the uplands of England was given up to the pasturing of sheep, and the export of wool to Holland and the Low Countries was our most important trade, these pack-ways, where they existed, and the high roads connecting these districts with certain seaports, were crowded with traffic. The villages and the village inns made considerable profits out of the wayfarers, and did all in their power to bring some portion of the wool-carrying trade through their neighbourhood. We come across memories of this once great industry in various parts of England when we see old inn and public-house signs, such as the Woolpack Inn, the Fleece Inn, the Staple Inn, and several other names which refer to the wool trade. 


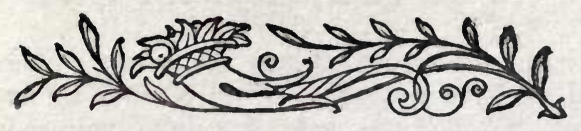

CHAPTER XI

SPRINGS AND STREAMS

A GOOD supply of water must be considered a necessary part of any community. In the case of large towns we are well aware that the health, prosperity, and even the lives of the citizens depend on the care taken to bring an ample supply of water into the town, and it is one of the first considerations of those who attend to the wellbeing of the people around them. In the country, however, where we should naturally think water would be easy to get, we very often find that a small supply of not very wholesome water is all that we can count upon.

It is always worth while finding out whence comes the water we drink. Perhaps it is drawn out of a river close to us; it may spring out of the ground near at hand, or come out of a deep well; sometimes it is collected far away in lakes and reservoirs, and brought to us for miles underground in pipes, or it is gathered from the roofs and collected in tanks and barrels in the garden on rainy days; sometimes we think it is just 


\section{STUDIES IN NATURE}

pumped up, or comes into the house somehow, and we have not asked from whence it comes. Now, whether the water we drink comes from far or near, from the hills above us or the ground beneath us, it all originally fell from the clouds as rain or snow. We know how it got into the air, for we studied that question when we talked about water-vapour. We must now try to find out what happens to it after it falls to the ground and before it reaches our houses.

In the first place it is clear, since it comes to us in so many different ways, that a good many different things may occur to it. It may, as we said in our chapter on the Earth, run into little rivulets, and these collect into larger streams, and so grow into the river from which we take our water. Again, some of the rain may sink into the ground and travel very slowly through the soil, and even gradually find a way through some of the rocks, until, coming to a rock through which it cannot pass, or finding a crack down which it can get away, it reappears to us in a spring of water bubbling out of the hill-side. If the rain that falls on the ground cannot run away in streams nor sink into the earth, it collects in ponds, which are only big puddles, and from there it gradually passes away as vapour into the air. Sometimes it will sink so far into the ground that we have to dig wells to reach it, and put in pumps to bring it 


\section{SPRINGS AND STREAMS}

up to us again. In all these ways, except from ponds, we may, if we and our neighbours are careful, obtain good drinking-water, and it is sad to think how often a good supply is spoilt for want of proper care.

In towns, as we said before, a very great deal of thought is given to the matter. It is worth while to take care when the health and happiness of many thousand people depend on the trouble that is taken and the money that is spent. It is often more difficult to get people to take much trouble for the sake of a few people in the country who cannot afford to spend much. Again, the large towns have often found themselves obliged to buy big tracts of country and get rights to convert valleys into lakes and bore very deep wells for pumping, and in all these ways deprive the country of some of its proper share of water. Then factories and mills until a few years ago were allowed to turn refuse and dirty liquids into the streams and rivers; towns and villages poured their drainage unchecked into the water, until even the fishes could not live in such an unwholesome place, and people along the banks who drank the water were almost poisoned.

If we wish to be quite sure that our watersupply is good and safe to drink, we must get it from a place where neither drains nor manufacturer's refuse have been able to reach it; 


\section{STUDIES IN NATURE}

where sunshine and air have been able to purify it, or where in passing through soil, gravel, and rock, it has left behind it whatever is not wholesome. Now the ground about cottages and farms is often not very clean, and if we take the water that is standing near them in ponds we shall find it far from nice. The rain also which sinks into the ground around them will have to travel a great way into the earth before it has left behind it all the impurities that collected in it as it sank through the soiled layer at the top. If we get our water from a well near houses, we must be quite sure that the well is deep, and that the surface-water cannot get into it, or else we must boil our water before we drink it, and so destroy some of the most unwholesome things that may have got in. A spring out of the hill-side, if we have the good fortune to be near one, is perhaps the best way of obtaining water in the country, and even then we must be careful not to let cattle and other animals mess the ground through which it runs. A deep well may be also very good; and a clear river, which has not been spoilt by thoughtless and selfish people who live above us, is a valuable possession.

We sometimes come across wells where the water has a peculiar taste or colour, and are told that certain diseases are cured by drinking or bathing in these places. These wells or springs do indeed give us a natural medicine, and if 


\section{SPRINGS AND STREAMS}

properly used may be of great service. Our forefathers, who had fewer doctors and hospitals than we have, often went to such spots, which are far more frequent than we, who do not require them so much, are apt to think.

There is, in truth, no such thing in Nature as pure water; all water has other substances in it, but usually these other substances are present in such small quantity that we are not aware of it. We do indeed know that some water is pleasanter to wash in than other; for instance, water that comes off or through a chalk hill is hard and difficult to wash in. Rainwater is said to be 'soft,' and is often collected to use for washing purposes, even where there is a plentiful supply of other water. When water passes slowly through soil, sand and rock, two different things happen to it. In the first place it is filtered; that is to say, it leaves behind most of the solid impurities it contains round the tiny spaces in the material of which the ground is made. In the second place it takes away with it some of whatever substance it passes through that can be dissolved in water, and carries this away invisibly, so that we do not as a rule find out that there is anything there. However, when we examine carefully the inside of our kettles, saucepans, and other vessels in which water has been kept, and especially where it has been boiled, we do find that something has been left behind in them which must clearly 


\section{STUDIES IN NATURE}

have come out of the water. So when water has travelled through chalk, there is a certain amount of chalk in it which makes it feel hard and rough to wash in, and will leave quite a thick covering of greyish powder inside any pan we use to heat it in. Rain-water has had no opportunity of gathering anything out of the soil, and the trace of gas it takes out of the air as it falls to the ground does not injure it, though in towns the air is often so full of smuts that the rain-water there is too dirty to use. Indeed, it is one of the blessings of a shower of rain that it washes the air we are going to breathe.

In medicinal springs, or in the natural mineral waters, we have cases where the water in sinking down into the earth has dissolved enough of the substances through which it has passed for us to notice, and for our bodies in some instances to be able to profit by it. Such springs of water are often found to be warm as well ; sometimes, indeed, they are almost boiling, from which we believe they must have come up from a great depth, since the earth is found to be hotter the further down we go into it. This warmth is probably the reason why there is so much mineral or other matter dissolved in them, since most substances are dissolved far more easily in hot than in cold water.

Much that is of interest can be learnt from watching the habits of animals with regard to the times, places, and manner in which they drink. 


\section{SPRINGS AND STREAMS}

They often seem to have very clear ideas on the point, and will prefer one stream to another, and go off together at certain regular hours to their chosen drinking-place. Sheep seem to require very little water; cattle want a good deal more. Some birds also seem to be frequent drinkers, and have at times great difficulty in a hard frost to find any piece of water that is not covered with ice. It is then a kindness to put out a saucer of water for them each morning, and after they have discovered it, and become accustomed to it, we shall have many opportunities of watching them, and of finding out what birds stay in our neighbourhood during the winter months.

Water plays such an important part in our daily lives, and is so necessary to our health and general well-being, that it is extremely wrong to do anything which may spoil the supply of it, either for ourselves or our neighbours. A little carelessness may injure many people's health, and a little thought and trouble may often give a good supply to a whole district. So important is it known to be that, in old days, wells and streams were often called holy, and were put under the especial protection of saints and other good men and women. By this means the people were taught to respect the gift of a plentiful supply of water, and be grateful for it ; they were thus persuaded to keep the ground around their spring clean 


\section{STUDIES IN NATURE}

and wholesome, and got lasting benefit from the precious gift. Sometimes the church was actually built near or even over the well, and though this for many reasons was not desirable, it shows us the right spirit of thoughtfulness and thankfulness. 


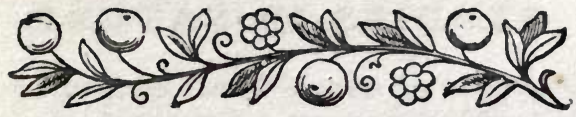

\section{CHAPTER XII}

SOIL

IN studying the subject of the soil, we are again considering a matter with which we are all familiar, since the soil is the principal covering of the surface of the land, the part which is nearest to us, on which we walk, and wherein all our plants and trees grow. In streets and roads we do, it is true, make efforts to get rid of the soil; we pave them with blocks of stone or wood; we cover up the soil to get a hard surface over which wheels can run easily, and on which we can walk in wet weather without fear of sinking in. Nevertheless, the soil constantly comes back again, perhaps as mud and dirt after rain, or as dust in dry seasons.

Soil, as we have already said, is made by the wearing down of other substances, as in the weathering of rocks, the rubbing together of stones, the decay of vegetable and animal matter. Even on pavements soil is always being created; for the wheels of our carriages and carts, and the iron shoes of our horses, in time wear away even the hardest granite, and form a layer of soil which has to be swept up and carried away.

Since soil is made by the rubbing and dis- 


\section{STUDIES IN NATURE}

solving away of many different sorts of things, it follows that there are a great many different kinds of matter in it. Some of them are of more use than others to the vegetable world; bence we hear farmers and gardeners speaking of rich and poor soils, of hot and cold soils, and we begin to ask what is the difference between them. Besides the particles of rock or mineral matter in soil, there is, as we said, a large amount of humus, or decaying animal and vegetable matter, which is particularly useful in binding together the tiny particles, in collecting and keeping the moisture, and in breaking up the soil so that air and heat can enter into it. Sand is an example of soil without humus; few things can grow upon it, water runs quickly through it, and its surface is alternately very hot and very cold. But sand, when properly mixed with decaying animal and vegetable matter, such as farm-yard or stable manure, and well supplied with water, will make an excellent soil, giving fine crops, and well repaying all the trouble which has been taken with it. Dust, as we know, is another form of soil which has lost its moisture, and therefore its power of cohesion or of sticking together. It can be lifted off the surface of the earth and blown about by the wind, and in towns we have to use wateringcarts to moisten the surface of the roads and keep the dust from troubling us.

The soil often varies in colour and quality 
in different parts of the country, according to the nature of the rock in the district, and this of itself is sufficient to tell us that it has been formed out of the substances around it. In chalk or limestone neighbourhoods, where the rocks are white and let water run through them easily, the soil is light in colour and dries up readily; where there is iron to be found the soil is red, as though coloured by rust; in river meadows where there is a great quantity of moist decaying matter, we get a rich dark warm soil, full of humus. Clay is a kind of soil which is found to be cold and heavy to cultivate; for the mineral substances in it are very finely divided, and stick so closely together that water cannot easily run through and the heat of the sun does not get far in. The size of the particles in the soil makes a great difference in its properties. If we crumble a piece of clay into a basin of water, the particles are so small that for a long time they are held up by the water and make it look muddy, just as in a fog we found that the small particles of water scarcely moved through the air. If we put sand into water it quickly falls to the bottom, leaving the water clear again, like a shower of rain which passes through the air.

The amount of moisture in the soil is one of the most important points that a farmer or gardener has to consider, since the crops that we grow both for ourselves and our animals 


\section{STUDIES IN NATURE}

all require moisture, but at the same time will not grow properly if the ground about them becomes soaked with stagnant water. Hence in England, where there is plenty of rain, we generally have to make plans to carry off the excess of water, or to drain the land, as this sort of work is called; while in hot dry countries the people try to find ways to bring water from the rivers back on to the land, in order to irrigate the crops, as they say. In autumn or winter, when the fields are bare, we may often see men busily digging channels in which pipes are laid and covered over. These are brought to the nearest stream or ditch, and will carry away the heavy rains of the spring and winter, thus leaving the surface of the ground in a good condition for the harvest. When the young plants grow up in springtime, they send their roots deeper and deeper into the ground, and follow the water level in the soil, as it gradually sinks lower during the dry summer weather. In this manner the roots find their way into fresh soil and get new supplies of food. Certain plants, such as carrots, for instance, have roots that go a long way into the ground; these keep the plants supplied with moisture in the dry weather, when plants, like lettuce and spinach, which have only surface roots, will dwindle away and die of thirst.

It is clear that everything which grows on the earth takes a certain amount of substance out 


\section{SOIL}

of the soil. In a wild country, where there are no men to interfere with the course of Nature, all these substances return to the land in due season in some form of decaying animal or vegetable matter. In civilised countries, however, this natural process of giving back does not happen, and each crop that is taken away leaves the soil a little poorer than before. It is true that any soil, however poor, always seems to be able to grow something. The sorts of plants we call weeds will often grow where useful crops fail, but to keep our soil in good condition, so as to get the best return from it, is a matter that requires thought and care.

Let us think for a moment of all the different ways in which soil, or rather substances formed out of soil, leave the land. There are the vegetables, such as potatoes, cabbages, peas, and many others; there are a great many different sorts of fruit; there is the hay and straw, the wheat and oats, the barley and rye, the turnips and mangolds. We must not forget the grass eaten by the cows and sheep, part of which is taken away from the land as milk and butter, meat or wool. We now see how necessary it must be to regularly put back into the soil some of the things we take away from it, and by constantly ploughing and cultivating it, to encourage the moisture and warmth to enter into it and still further break up the grains of rock. The work of putting substances back into 


\section{STUDIES IN NATURE}

the soil, and thus replenishing the supplies of food for the plants, is called manuring, as we most of us know, and like drainage and irrigation requires to be done carefully. Plants require tiny amounts of many sorts of things ; they often want them in one particular state or form, and too much manure may be as bad for them as too little. They will die of something like thirst if the ground is over-manured, for the water in the plants, instead of passing up into the leaves and flowers to take the place of that given off into the air, will go down into the ground to try to weaken the strength of the mixture of substances in the soil.

Another effect of adding manure is to warm the soil, and in cold districts this is very necessary. Farm-yard manure is decaying animal and vegetable matter, and, while the process of decay goes on, and the substances in it are broken up and altered in character, the heat which was stored up during the period of growth is given off and passes into the soil. We often see steam rising from a heap of manure, and know that it is used in many ways, especially in the garden, as a source of heat. Manure may also do good by making heavy clay soils less dense by the mixture with other substances. In this way sun and air get in more easily, and the land becomes less cold.

We have spoken of the results of drainage, of irrigation, and of manuring. We must now 


\section{SOIL}

briefly consider the most usual, and probably the most necessary, method of improving the soil ; that is, the method of cultivation. The farmer has his plough, his roller and harrow, the gardener has his spade, rake and hoe, with which the ground is constantly stirred up and kept in the best condition to help on the growth of the plants. By ploughing and digging the soil is broken up afresh each year; new surfaces are exposed to the action of the frost, rain, sunshine and wind, and new supplies of food are thus brought within reach of the plant-life. The insects and grubs that harm the crops in summer, and lie hidden in the ground in wintertime, are turned up to be killed by the frost or eaten by the birds. After the seed is sown, the ground is rolled or pressed down, so that the soil may settle closely about the tiny seeds, keeping them well supplied with warmth and moisture. Then, when the plants begin to grow, comes the harrow or rake, to disturb the soil again, breaking up the minute channels in the surface of the ground through which the water has found its way into the air, and thus encouraging the moisture to flow up through the roots into the plants, bringing its supply of food for them with it. The weeds also have to be constantly collected and destroyed, or else they will take the food that the crops require, and scatter their seeds over the land to grow up afresh the following year. 


\section{STUDIES IN NATURE}

People who have much to do with land can often tell by the look of the ground and by the appearance of the crop on it what substances it requires, and of what treatment it is in need. They will know what sort of manure to put on it, and the best time to lay it on; for land that is properly manured one year and has crops grown on it in the right order, will not require further attention in the way of manure for some time. It will be several years before the substances added to it are taken out by the different crops grown on it. Indeed, some plants, such as beans, peas, and clover, have actually the power of improving the soil in certain ways, and leave it in a better state for the next year's crops. They are able to take the nitrogen out of the air and store it up round their roots in the ground; and nitrogen is one of the substances which it is most necessary to plants and animal life. 


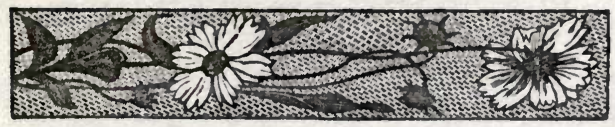

\section{CHAPTER XIII}

\section{FIELDS AND HEDGEROWS}

When we look over a large tract of country, one of the first things to draw our attention is the shape, size and colour of the fields, and the way in which they are separated from each other. In some districts the fields are small, and their boundaries seem to run hither and thither across the face of the land without any particular reason. In other places the fields are large and square, and the partitions between them are straight and uninteresting. Now, although there does not appear to be any very general rule on the point, on the whole we shall find the small fields in pastoral countries and the large ones in agricultural districts. If the farmer has to provide morning and evening pasture for his cows, meadows for his calves and other young animals, and grazing-ground for his sheep and lambs, he will require a good many enclosures in order that he may, if necessary, separate his stock and vary their feedingground, and give the grass a chance to grow up again when it has been eaten off and trampled on. On the other hand, if he intends to grow 


\section{STUDIES IN NATURE}

great quantities of corn and other crops, he may just as well have big fields. Less ground is lost in hedgerows, and it is easier for a plough, harrow, or reaping-machine to work up and down a large tract of land than to be continually going from field to field and starting afresh. Indeed, in some of the corn-growing parts of England, it is only quite recently that the fields were divided up at all, as little ridges of soil or narrow bands left uncultivated were sufficient to mark out the different properties.

We may perhaps say, without being far from the truth, that there are three kinds of fields. There are the permanent pasture lands on which from time immemorial the animals have grazed, and it is not difficult to recognise their fine close grass and soft springy turf. Then there are the fields or leys on which we find grasses and clovers of the quick-growing sorts ; these fields for a year or two are used for hay-crops and pasture, and afterwards are turned up again by the plough and put to other purposes. Thirdly there are the fields on which some sort of crop other than grass is generally grown, the kind and the order or rotation of the crop differing according to the nature of the soil and the custom of the country.

It is a common mistake among unobservant people to think that all grass is the same. Most men and women have been obliged to realise that there are at least two kinds of clover, since 


\section{FIELDS AND HEDGEROWS}

one sort has without doubt large red flowers and another has small white ones. But there are a very great many different varieties of grasses; as many as thirty are well known and are used to make good pasture, without counting many more that for several reasons are not worth growing. Some of us can perhaps distinguish between the various blades, thick and thin, coarse and fine, dark and light, which are the leaves of the grass-plants, and it is much easier to find them out in a hay-field in summer-time when the grass has grown long and is in flower. Even when we know the different kinds by sight we are a long way from being able to tell, as a good farmer or labourer will, which varieties do credit to the land, and which sorts are only thriving on account of poor soil and bad cultivation. Again, should we be so fortunate as to know the good and bad kinds of grass when growing or in flower, we have yet to learn the different appearance of the seeds, since it is as seeds that they must first be put into the ground. This, truly, is such skilled labour that few people will undertake it for themselves, and find it wiser to get their seed from trustworthy seed-growers and merchants.

It does not by any means follow that because one sort of grass or clover will grow well in one district, that it is the right sort to use in another. Here again a special kind of knowledge, only to be gained by observation, is required. We have 


\section{STUDIES IN NATURE}

to consider the depth and quality of the soil, the amount of moisture, of exposure, and also the results we desire to obtain. There is one kind of turf on the chalk downs, another in the river meadows, another on the cliffs by the sea. We can hardly speak of the grass near a sandy windswept shore as turf at all, and on some clay-land it seems impossible to get a close fine covering. In these cases we must do the best we can; if we want grass and the good sorts will not grow, we must choose poorer kinds that will, and our intelligence and observation will be required to know what is the best possible under the circumstances.

The hedgerows of England, with their wealth of flowers, their variety of outline, their occasional forest tree, give much of the especial beauty and grace to an English landscape. In no other country do they exist to anything like the same extent. They may not be, and probably are not, entirely wise from the point of view of geting the most return out of the land, but they are very precious to us for many reasons, and much of the harm they do can, as is usually the case, be prevented by a little care and thought. We have only to go from a country of hedgerows into a country of stone walls, or worse still, of wire fences, to see what a cherished possession our hedges should be.

In considering anything, we must first of all ask ourselves for what purpose it exists, and it 


\section{FIELDS AND HEDGEROWS}

is quite clear that no hedge is really a good hedge if animals or even people can get through it. Hence, if we are to have hedges at all, they should be close, compact, and perhaps prickly. A second use of hedges is to afford shelter to animals, and also to give them shade in summertime. For these purposes we again want compact hedges of a fair height, while an occasional tall tree will ward off the extreme heat of the summer sun. But we do not want the roots of the big trees to take the nourishment away from the crops on the fields, nor to scar the surface of the ground and catch against the farming instruments, nor to let the drip of water from their leaves or the excessive shade destroy the vegetation underneath. So, strictly speaking, we should choose our hedgerow trees on account of the compact habit of their roots and the lightness of their foliage.

If we look at a good many hedges, we shall probably find that they are largely made up of hawthorn, may, or quick, as it is variously called, and long experience has shown that this is a wise choice. Let us think what properties we shall require in our hedge-tree; it must be stiff, difficult to get through, it must not die when it is constantly cut back, nor dwindle away under the shade of the big trees. Clearly, also, no part of it must be poisonous to animals at any part of the year; we could not put yew in a fieldhedge on any account. Hawthorn has all the 


\section{STUDIES IN NATURE}

properties we require, and many hedges are made entirely of it. Beech and holly are also frequently used, and both are found to be good in certain parts of the country, the one on a chalk, the other on a clay soil.

We sometimes hear people complain because the hedges are tidied up and kept in order; they say it spoils them, and they would perhaps like to have them straggling all over the ground. Now it would be much more reasonable if people complained when the hedges were not kept in order, for it would show that they understood something about the nature and use of a hedge. Hedges should be regularly trimmed and clipped every year, and sometimes twice a year, for if they get too big and top-heavy the weight of the snow on their branches in winter-time may break them down; while if they are choked up with plants and brambles below, the bottom branches will rot and die, so that holes and bare places begin to appear. Moreover, the untended sides of a hedge may become nurseries for growing bad weeds and harmful plants, which will afterwards scatter their seeds over the land. Certain tiny forms of life abide for a time in various hedgerow plants and afterwards appear as blight of various sorts to injure and destroy the crops. For all these reasons then a hedge should be kept clean and tidy, and should be regularly attended to by men who understand these matters. 


\section{FIELDS AND HEDGEROWS}

Firm, well-kept hedges, and clean, wellcultivated fields, are what we should always look for and hope to see in the country. They bring credit alike to landowner, farmer, and labourer, and show that care and intelligence are bestowed on the upkeep of the land by all who are concerned in it. 


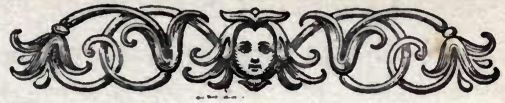

\section{CHAPTER XIV}

\section{TREES AND WOODS}

TREeS form a very important part of the vegetable covering of this earth. We have already found out two ways in which they are useful to us, when we spoke of the storage of carbon in coal and the re-making of the supply of oxygen in the air. We must now study them a little more fully, and especially consider the effect of them when they grow together in great quantities, as they do in our woods and forests.

England is certainly a country of many trees, but at the same time we have not really much woodland, and there is now hardly anything left that we can call forest. This was not always the case, but for various reasons, some of which we shall perhaps be better able to understand later on, for many hundred years people in England have been cutting down more trees than they have re-planted to take their place. Probably in early days the face of the country was largely covered with forests, and even in old maps we can often find that woods are marked down in places where we can now see very little more than hedgerow trees. Men cleared away the woods in the first place in 


\section{TREES AND WOODS}

order to provide themselves with timber and fuel, and then to get open spaces on which to grow their corn and feed their flocks.

This clearing away of the trees, which seem to have been the natural covering of the earth, is a very unfortunate thing when it is carried to a great extent, and though England has not suffered so much in this way as some other countries, we may yet fairly find reasons to regret it. In certain lands the mischief thus done has been so serious that the Governments have had to consider the whole question of woods and forests, and have re-planted trees in large quantities.

To understand this, let us begin, as we have always found it wise to do, by asking ourselves the uses of these trees, woods and forests. In the first place, we shall probably think of the endless ways in which we require wood in our houses; the floors, the stairs, the furniture are all made of it. We also want firewood, and other kinds of timber to build our carts and carriages. Clearly we must have a greal deal of many different sorts, and it is a pity to get this from other countries if it is profitable and pleasant in all ways to grow it ourselves. But this is not all; questions of profit and convenience need not be the first or the only reasons to influence us. Let us consider the effect of trees on the land, the water-supply, and the climate. 


\section{STUDIES IN NATURE}

Now, if we go into a wood on a hot summer day, we find that it is cool, and often notice that the ground beneath the trees is moist, although the land out in the open may be almost parched up. Again, if we go into a wood in winter-time, we find it warmer than the fields, and very often it seems to have entirely escaped the frosts. The leaves on the trees shade the ground in summer-time, keeping it cool and moist, preventing rapid evaporation, while in winter-time the branches overhead and the fallen leaves stop a great deal of the radiation, and help to preserve the warmth in the soil. Trees also break the strength of the winds and give shelter to the land around them; thus they add greatly to our own comfort, and help towards the well-being of our flocks and herds.

If we look at the roots of a tree we see how they spread out into the ground about them, perhaps clinging to pieces of rock and so binding the soil together in a close mass. The water during a rain-storm can only trickle slowly and gently through the firm network of roots, and cannot at once run off the land into the streams, loosening and washing away the soil with it. In this way the trees with their roots entangle the soil, which in its turn holds back the water, some of which remains in it while the rest soaks gradually right down into the earth. Floods are thus prevented or lessened, 


\section{TREES AND WOODS}

and instead of their useless waste the water is stored up in the earth during the wet seasons; the underground springs and watercourses are filled up, and are therefore able to give out a constant supply in dry weather. Trees themselves require large quantities of water; they suck up that which stays in the soil within reach of their roots, and breathe or transpire it out again through their leaves into the air, and this, occurring throughout a large forest, greatly increases the amount of moisture in the air, and will therefore probably influence the climate of the country and possibly affect that of the world.

The way in which trees ought to be grown, and the kind of tree to grow, must clearly depend on the purpose for which they are required. In our parks and gardens we may have handsome spreading and flowering trees, which are grown for ornament rather than use, and have great branches reaching out on all sides. But such trees do not give the straight trunks that the true forester loves to see and the timber merchant prefers, trunks that can be sawn up without waste into long planks. These must be cut from trees which have been grown close together in a wood or forest; so close that the tops shoot straight up towards the sun and the side branches die off for want of light and air and leave long smooth clean stems.

Trees begin to grow each spring and con- 


\section{STUDIES IN NATURE}

tinue throughout the summer, but the actual increase in the height of the tree and length of its branches takes place in a very short time, generally during a fortnight or three weeks at the beginning or end of May, according to the kind of tree and the character of the season. We can easily find out how much a young tree adds each year to its branches by measuring it at the beginning and end of the month. After that, the tree spends its strength in filling out the new growth and thickening its trunk, unless it is grown in a crowded place, when the stems never become very thick, until some of the trees are cut down and allow the sunlight and fresh air to reach the trunks of those that have been left. Trees are like people in one way, they grow for a certain number of years and reach their best time of life. They should then be cut down if they are wanted for use, for after a while they begin to get old and to decay, and then their timber is no longer so valuable.

When a tree is cut down, we generally see that the wood has grown in rings round the trunk, each ring marking the advance of a year. These rings are chiefly found in trees that grow in temperate countries, like England, where there are distinct seasons of growth, and seem to depend on the time of year when the wood was formed. In trees grown in the hot climates of tropical countries, where there is not much difference between winter and summer, we do 


\section{TREES AND WOODS}

not usually find these rings. By counting them it is often possible to get some idea of the age of the tree; but the rings themselves vary in thickness, according to the age of the tree, their distance from the centre of the trunk, and the character of the season in which they were formed. We can also best study the growth of the bark when a tree has been felled, and shall notice among other things that it is often the home of many beetles and insects. Some of these are very destructive to timber, and are especially apt to breed in rotten and decaying wood. We shall therefore find that the bark is usually stripped off the trees before they have been long cut down, and it is wise to take away the old tree stumps lest they should become centres of insect-life which would spread afterwards throughout the forest. The birds that we see in woods are nearly always insecteaters, and often have beaks which seem to be made on purpose to pick the beetles out of the bark; in this way they help to keep the trees in good condition, and should be left in peace and encouraged to stay about.

There is a curious thing we may perhaps notice either in trees when they are growing or in timber after it is cut down. If we look attentively at the bark of certain trees, we shall see that it does not appear to be straight but grows round the tree, sometimes to the right hand and sometimes to the left, in corkscrew 


\section{STUDIES IN NATURE}

fashion. This property varies very much according to the place in which the trees are grown, and is not always the same even in trees of the same sort ; indeed, one tree will sometimes show both directions of twist. The growth of the tree is evidently in an upward spiral or curved direction, and when such a tree is cut down and sawn into planks we shall have a kind of timber that is apt to warp.

Forests and woods give shelter to a great many different sorts of animals, none of which do them much harm, except rabbits, which are so mischievous that we ought never to see them where trees are properly valued. Rabbits are not native English animals, but were brought in from rocky districts in the south of Europe, and have been allowed to spoil a great deal of country.

In times of war, forests are often burnt or cut down to prevent people from hiding in them. and on this account large forests were destroyed in England during the Civil Wars. In Scotland and Ireland the same destruction has taken place, and the districts have not been replanted, for it is unfortunately far easier to cut down trees than to replant them.

The most useful trees are generally found to be those which give us the hardest wood, and it is quite easy to get some idea of the hardness of the different sorts of wood by getting pieces from the trees themselves, or from the carpenter, 


\section{TREES AND WOODS}

and trying with a penknife which are the easiest to cut. Oaks and ashes are among the hardest of our English trees. Firs are largely used in many ways for flooring and building purposes. Beech was more grown in the days when wood instead of coal was wanted for making fires, for beech-wood burns steadily and quietly, and at the same time gives out a great quantity of heat. The trees that grow near rivers and in moist places have usually, as we might expect, soft kinds of wood; such are the poplars, willows, and alders.

The oak is perhaps the tree that we feel specially belongs to England, in spite of the fact that it is found in all the neighbouring countries, and that we import large quantities of it from abroad. The old form of its name, 'aik' or 'ak,' occurs in village names in many parts of England; we find several Actons, and also Akeley Akenham, and Aikrigg.

A hundred years ago a great deal of oak was required to build the wooden ships for the navy, and it was felt to be a patriotic duty to plant large quantities of young trees to keep up a sufficient supply. At all times the acorns that fall from the oak trees have been found valuable for feeding the swine in autumntime, and when the pigs are hunting about for food they are also treading some of the acorns into the ground and burying them in the earth. This gives the acorns a better chance of grow- 


\section{STUDIES IN NATURE}

ing than if they were left lying out on the surface of the ground, and helps to provide for a succession of young trees. The bark of the oak tree until quite recently was also an extremely valuable crop, for it was used in the preparation of skins or tanning of leather. Now, however, our men-of-war are built of steel, our pigs are not so often driven out into the woods, and the tanning of skins can be done without the use of oak-bark. In spite of this the value of oakwood has steadily increased, and the supply of good wood in England is not equal to the demand.

The gradual decay and fall of the leaves marks, as we know, the autumn season, and then in towns and gardens we see men busy in sweeping up the leaves and carrying them away. This may be necessary in parks and exposed gardens where the wind might scatter the leaves about, but in big sheltered woods the leaves lie under the trees, helping to keep the roots warm and moist in winter-time, and when in the course of time they decay, they give back to the soil the substances the tree took from it to make them. In Nature there is no waste ; the tree gives back to the air some of the moisture that fell as rain, and the leaves return to the soil out of which they were made. 


\section{CHAPTER XV}

\section{VILLAGES}

IN what exactly, we may perhaps ask, does a village consist? How many or how few houses will make a village? It is quite likely that we should each of us answer these questions a little differently, and it is therefore worth while to stop for a few minutes and think what we mean by the word ' village.'

It is certain that every village must have begun with a few houses only, perhaps but one, and grown gradually. Very rarely do people set to work and build a whole village at once; it does happen sometimes, but these are not the sort of villages that we are considering. Some villages go on growing until they become small towns, and others increase until they are great cities, and take in many villages around them which once stood in open fields. We occasionally hear of deserted villages, where nearly all the people have gone away, and the cottages are falling into ruins. How soon does a collection of houses become a village, and when also does a village grow into a town?

Now, though we may many of us be quite sure that we know what a village is and what 


\section{STUDIES IN NATURE}

we expect to find there, it is not always easy to describe it to other people, nor is it certain that they would entirely agree with us. Still we may perhaps find a few points about our village in which we should all be at one.

In the first place most of us would expect to find country all round a village, and gardens to its houses, and I think also some common meeting-place, usually the church, in its midst. These things seem to be necessary. When a village is too small and scattered to have a building in which its inhabitants can join together for worship, it is but a collection of houses without a centre for its common life; we might perhaps call it a hamlet. When it is so big and crowded together that we cannot see out along the streets into the country, and there is no room in it for gardens and greens, it has become a town, and ceases to belong to our country life. The true village is a gathering of households of various ranks and many occupations, living near enough to each other to share the advantages of common social life, and yet sufficiently surrounded by country to keep the privileges of daily intercourse with Nature and natural objects.

We generally find all these things in our English villages; the country, the gardens, the church, and the people of various stations and occupations. We do not want all churches or all farms; we do not want everyone to be a 


\section{VILLAGES}

labourer or a clergyman; but we want to find someone to fulfil each worthy occupation of life, and to make the village as far as possible selfsupporting.

Let us try to count up the different people we might hope to find in our village. We should want a clergyman for the church, a schoolmaster or mistress for the school, and perhaps a doctor. The landowner should live near his village, share the life of the inhabitants, and see that the land, the houses, and the cottages are all well cared for. Next would come farmers to grow the corn and meat, labourers to cultivate the soil, shepherds to attend to the sheep, milkmen and maids to milk the cows and make the butter and cheese. We should require a shoemaker or cobbler, a smith to make and mend our carts and shoe our horses, a carpenter and a mason to build and repair our houses, a postman to carry our letters, and perhaps it would be as well to have a policeman to keep our boys out of mischief and warn away undesirable people. We might add to these a brewer to brew good wholesome ale, and an honest innkeeper to refresh the wayfarers and to welcome the strangers who chance to come to our village. We now have our little community fairly complete.

In old days there were many other industries besides the ones we have just mentioned; such, for example, were spinning and weaving, bas- 


\section{STUDIES IN NATURE}

ket-making, straw-plaiting, wood-carving, lacemaking. Some of these handicrafts do indeed survive in favoured places, but for the most part the village folk are forgetting their beautiful workmanship. Before the days of railways, when it was difficult and costly to send goods about the country, each village would grow and make most of the various things that are necessary to carry on the daily life of the people. We know how much we require for even the simplest household, and can easily gain some idea of the variety of village life a hundred years ago. It is true that it is now much easier to bring food and stuffs from other parts of the country, where they can perhaps be got cheaper, and for this reason many of the old industries have unfortunately died out, and people will often buy things brought from a distance that might have been better made by themselves or their neighbours.

If we now begin to consider what buildings we shall want in our village, we shall not have much difficulty in counting them up. There must be a church, a school, farms, barns and cowsheds, a wind-mill or water-mill not very far off to grind the corn into flour, a malt-house and brewery, a post-office, an inn or public-house, workshops and smithy, and, most important of all, houses and cottages of all sizes, surrounded by gardens, for the people of the village to dwell in. 


\section{VILLAGES}

Buildings are always worth studying; they have a great deal to tell us about the customs and the skill of those who built them. We may learn something from noting the materials of which they are made; whether of stone, brick, or timber; and how they are covered over, whether by tiles, slates, or thatch. Each part of the country has some peculiarity of its own, either in materials or workmanship. We find thatch used where corn is grown, and good straw is therefore easily to be had; and timber is seen where woods and forests have been plentiful. Bricks are common in districts where there is clay out of which to make them, and stone houses are to be found wherever a suitable rock is to be quarried.

Of all the buildings in a village, the one of greatest interest is usually the church ; because, as we said before, it has been the centre of the common life from the earliest times, has been added to and improved when the people were prosperous, and has fallen into disrepair and been neglected when they were poor or careless. So by studying the church attentively it is often possible to trace out the ups and downs of a village.

Let us go into some village church-yard and see what we may learn. Around us are the burial places of the former inhabitants, whose grandchildren and great-grandchildren are playing in the lanes, using the same words and 


\section{STUDIES IN NATURE}

perhaps even like in countenance to their forefathers. We can read their names, their professions, and find out where they dwelt and to what age they lived. The church is perhaps built of several different materials-stone, or brick, or rough cast over one or both of these ; each piece marks a period of its history. The windows may be plain and square, or they may have pointed and carved arches over them, or simple round arches, which are very old, and were chiefly made many hundred years ago. We must look if there is a tower or a spire from which the bells can be heard ringing out over the tops of the trees. Inside the church are other memorials to men and women who lived in this district and were beloved by their friends and families. We read their names and whence they came ; we are told how they served their generation or helped their neighbours. Indeed, if we really wish to find out the history of our country and see by what means the national life has gradually grown up and altered, we should do well never to leave a church near us unvisited, and to remember that every part of a village, however lowly, has its own story to tell us.

We learned something about the origin of villages when we spoke of their names. Many seem to have grown up for purposes of convenience round a well, a bridge, or a ford. Others arose where two roads met or crossed 


\section{I L L A GES}

each other; others again sprang up round the coast where there was a safe harbour for fishing boats. Sometimes the villages seem to nestle for protection under the shelter of a hill, or stand on rising ground to escape the floods of a river valley. When once we understand the character of village life, we can often find out for ourselves the reasons both for their names and their situations.

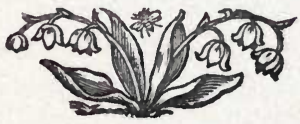




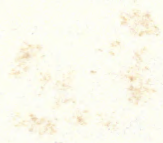

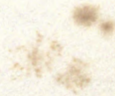

$$
\begin{aligned}
& \text { xys: }
\end{aligned}
$$


2

is.

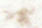

$x^{4} x^{2}$

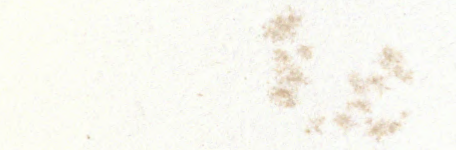

2

xis

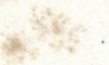

an 



\section{UNIVERSITY OF CALIFORNIA LIBRARY}

Los Angeles

This book is DUE on the last date stamped below.

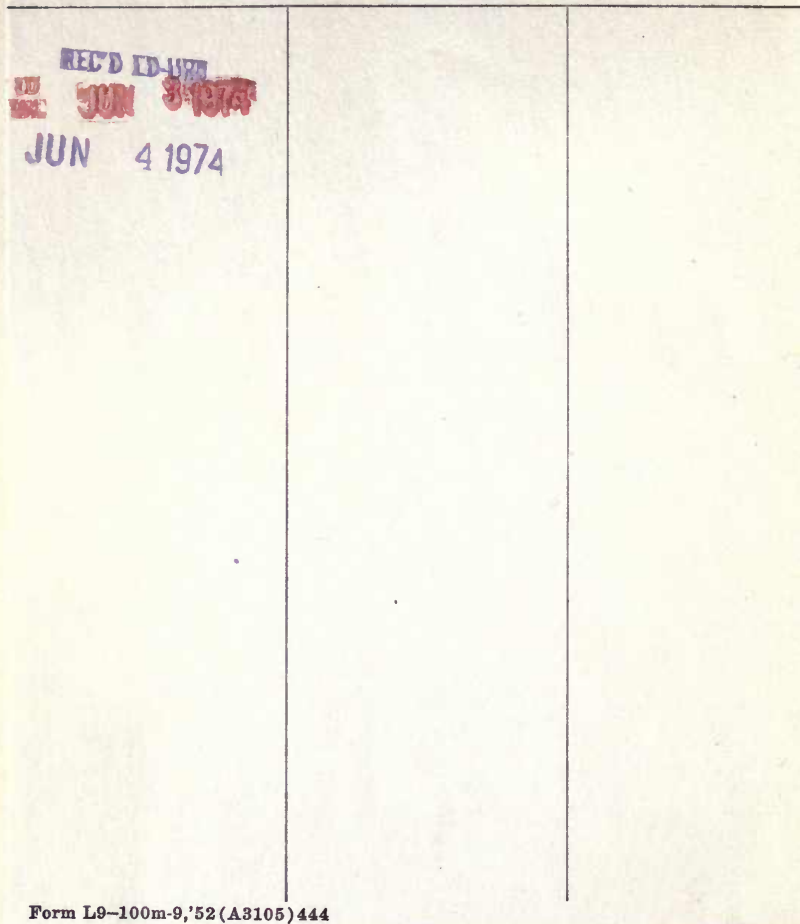

Form L9-100m-9,'52(A3105) 444. 
